\title{
Comparing adaptive capacity of Arctic communities responding to environmental change
}

\author{
Matthew D. Berman $^{1}, \underline{\text { Jennifer I. Schmidt }}^{1}$ and Gary P. Kofinas ${ }^{2}$
}

\begin{abstract}
Adaptive capacity (AC) is a widely used concept denoting assets or resources that people or a system can draw upon to cope with environmental change. When applied to a community, careful definition and measurement of AC is essential for identifying patterns and generating findings that may be useful for policy and transferable to other places. We identified and compared measures of 22 indicators for eight communities on Alaska's North Slope, based on consistency with theory, availability of data, and measurable community differences. Despite many cultural and institutional similarities, we found systematic differences among communities in each of the seven AC domains measured. Although every community had strengths in some domains, we could divide communities into three groups: high overall AC (one community), moderate overall AC (four communities), and low overall AC (three communities), based on average rank order across all domains. The comparative approach we developed can be helpful in identifying productive policy opportunities for strengthening community AC.
\end{abstract}

Key Words: adaptive capacity; Arctic communities; climate change; Inupiat; local institutions; oil development; resilience

\section{INTRODUCTION}

Climate change increasingly affects social-ecological systems (SESs) of rural communities, especially in the Arctic, which is warming faster than other regions (Carson and Peterson 2016, IPCC 2019). Arctic communities are also simultaneously adapting to other forces of change such as resource development, changes in national policies, and globalization. As communities navigate these changes, some may fare better than others in maintaining well-being, population, and SES resilience. How can one understand and measure the main factors predicting different outcomes for arctic communities, and potentially use the findings to improve outcomes for communities overall?

To address this question, we undertook a comparative study of the eight largely Iñupiat communities of the North Slope (NS) region of Alaska. Most NS residents combine wage jobs and other cash income with subsistence harvesting in a SES that has proven resilient over many years, as residents have adapted to rapid environmental and social change (Braund and Kruse 2009, BurnSilver et al. 2016) Whether those positive outcomes can be maintained in the future as the changes continue and intensify is uncertain, and depends on community adaptive capacity.

Adaptive capacity (AC) is a widely used concept denoting assets or resources that enhance the ability of people individually or collectively to accommodate change and variability without causing harm (Turner et al. 2003, Adger 2006, IPCC 2014). The objective of the study was to develop and apply methods to provide empirical comparisons of AC across multiple communities. Evaluating the specific role of $\mathrm{AC}$ in reducing community vulnerability is challenging, requiring a framework that is both theoretically consistent and can distinguish drivers of change from components of AC and SES outcomes in a comparative empirical setting (Berman et al. 2017). We offer such a framework, and apply it to discuss drivers of change and AC that might affect well-being in NS communities.

Vulnerability, resilience, and adaptive capacity Over the past two decades AC has emerged as a central concept in vulnerability assessments, to a great extent in response to concern for climate-linked environmental change, and in resilience theory, motivated by concerns for a larger set of socialecological changes. In early climate change assessments, AC was defined as the ability of a system to adjust to change (including variability and extremes) to reduce potential damages, take advantage of opportunities, or cope with the consequences (IPCC 2001). Many studies have focused on introducing and refining various "vulnerability frameworks" to explore the relationship between three linked elements of vulnerability: exposure, sensitivity, and AC (IPCC 2001). Central to this enterprise has been identifying the critical variables (Smit and Pilifosova 2001, Smit and Pilifosova 2003, Turner et al. 2003), barriers (Brooks and Adger 2005), and the nuanced dimensions of AC (Hovelsrud et al. 2010). Scholars have focused on a variety of themes, including institutional arrangements and governance systems (Young et al. 2008, Armitage and Plummer 2010, Folke et al. 2005), gender (Denton 2002), perceptions of risk (Blair and Kofinas 2020), the role of power dynamics (Woroniecki et al. 2019), processes of navigated transformation (Olsson et al. 2006), psycho-social conditions (Grothmann and Patt 2005), livelihood diversity (Ellis 1998, BurnSilver and Magdanz 2019), and forms of social capital (Adger 2003).

Studies applying the resilience lens have looked more broadly to consider the social-ecological dynamics and their implications to adaptability (Walker et al. 2004, Chapin et al. 2009). For example, Carpenter and Brock (2008) noted the role of the adaptive cycle and extent to which traps (conditions that prevent adaptation), such as institutional rigidity, can affect outcomes. The conceptual relationship between vulnerability, resilience, and $\mathrm{AC}$ has taken a variety of forms in the literature (Cutter et al. 2008). For this study we focus more narrowly on the use of the term AC as a set of assets (resources or tools) that people can use, either individually or collectively, as they undertake activities to reduce vulnerability and promote positive well-being outcomes in response to various drivers of change (Smit and Pilifosova 2001, Adger et al. 2007; Fig. 1). These activities also increase SES resilience if they maintain or strengthen the structure and function of human-environment interactions; however, they 
promote SES transformation if they change these system properties (Folke 2006, Engle 2011). This interpretation of AC aligns with the concept of AC that promotes robustness of the SES (Anderies et al. 2004).

Fig. 1. Vulnerability (likely outcomes falling below a threshold) depends on driver level or rate (exposure), initial well-being, sensitivity (incremental change in likely outcomes, slope of curve), and adaptive capacity (AC). AC increases the range of driver states with likely outcomes above the threshold.

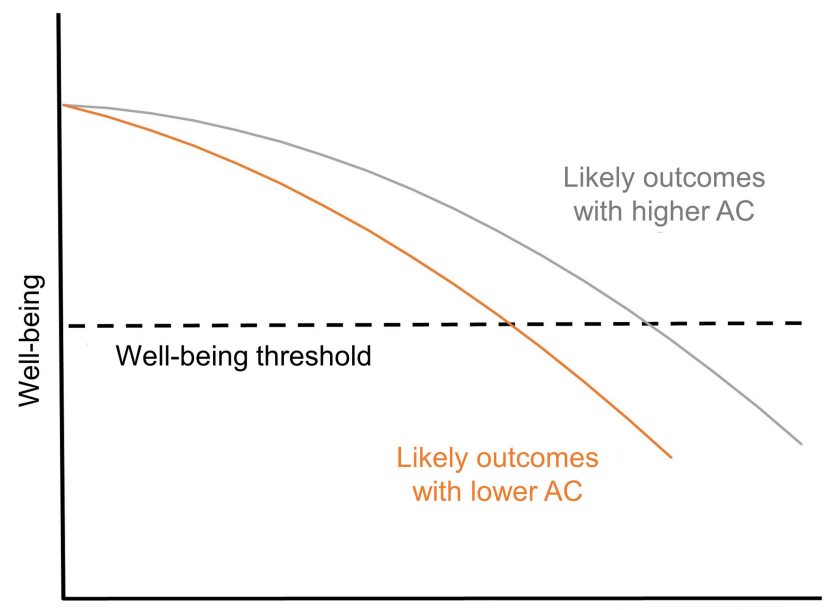

Driver (exposure)

For the most part, vulnerability analyses, and to a lesser extent resilience theory, have been based on qualitative analyses of one or several case studies. Relatively few studies have sought to measure AC using quantitative data, and even fewer of these have undertaken comparative studies (Defiesta and Rapera 2014, Lockwood et al. 2015). Although a multitude of studies have discussed vulnerability, resilience, and adaptive capacity in the circumpolar Arctic region (Arctic Monitoring and Assessment Programme 2017), we are not aware of any studies that used quantitative as well as qualitative data to compare $\mathrm{AC}$ systematically among Arctic communities. Our comparative study of AC of the eight Iñupiat communities in Alaska's North Slope region was motivated by the need to bring greater rigor to community assessments of AC in ways that both support theory building and policy making. We undertook this enterprise with the understanding that comparing $\mathrm{AC}$ with mainly publicly available data alone is insufficient by itself to provide a full assessment of community AC. A full assessment would include an evaluation arising from a strong participatory process led by community residents. The logistics of coordinating such a process with a large number of communities would be difficult and labor intensive. This analysis explores what is feasible using publicly available data.

\section{The Alaska North Slope region and communities}

The North Slope Borough (NSB) is a county-level government jurisdiction encompassing about $230,000 \mathrm{~km}^{2}$ of Arctic Alaska (Fig. 2). The borough's population of 9430 (U.S. Census Bureau 2010) includes over 2600 oilfield shift workers residing in industrial work camps, with the remainder residing in eight small predominantly Iñupiat communities. North Slope Iñupiat, an
Indigenous Inuit population, continue to harvest wild foods from the land, rivers, and ocean with hunting and fishing activities that typically involve cooperation among multiple households (BurnSilver et al. 2016). These subsistence activities maintain culture and social connections as well as providing food (Braund and Kruse 2010, Kofinas et al. 2016a). Utqiagivik (formerly Barrow), county seat for the NSB and headquarters for Arctic Slope Regional Corporation (ASRC), is the largest community, with a population of 4469 , and has the lowest concentration of Indigenous residents, at $61.2 \%$. The other communities are smaller, with populations of 244 to 672 , and are over $80 \%$ Indigenous (U.S. Census Bureau 2010). Most are located along the Arctic Ocean. Anaktuvuk Pass is located inland in the Brooks Range, and Atqasuk and Nuiqsut lie inland on north-flowing rivers that provide access to coastal regions and marine resources. The incorporation of the NSB in 1972 allowed NS communities to collect property tax revenues from oil and gas infrastructure to improve public facilities and provide services and jobs to residents (Knapp and Morehouse 1991). New services offered by the NSB included resource management critical to subsistence harvesting.

Fig. 2. The North Slope study region and communities. ANWR: Arctic National Wildlife Refuge. NPRA: National Petroleum Reserve Alaska.

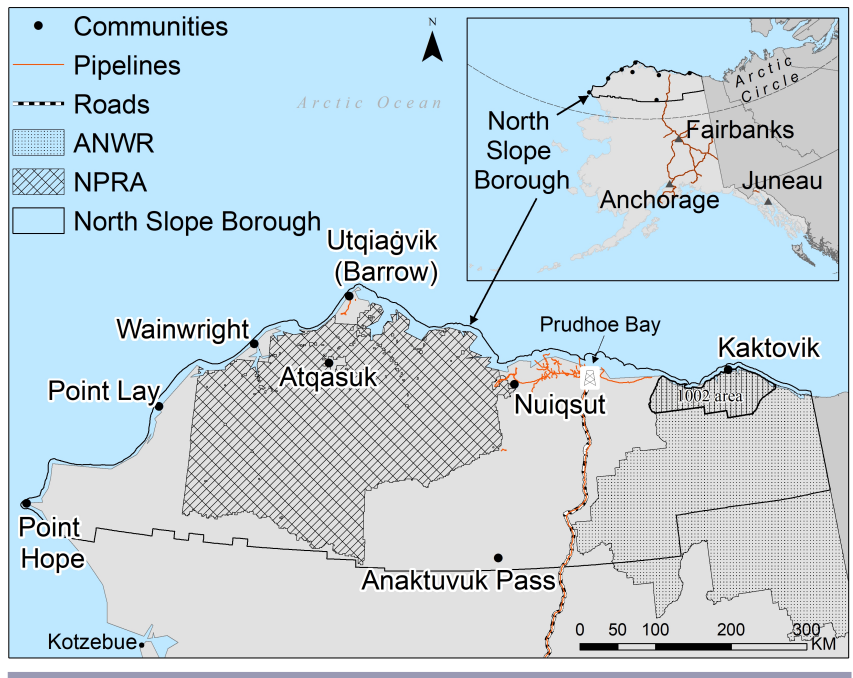

Drivers of change for Alaska North Slope communities

Drivers of change are forces affecting the community, which could be environmental, social, or a combination of the two. Although they appear in the literature as links among system components as well as external forces, we consider only external drivers, which we refer to simply as "drivers". We use drivers rather than the more conventional term "exposure" to emphasize that they are exogenous to the region. Sensitivity, that is, the degree to which a disturbance affects or modifies the system (Gallopin 2006), has been treated in a variety of ways in the vulnerability literature. Here, we define it functionally as the incremental change in the system caused by a small change in a driver: i.e., the slope of curve in Fig. 1. Vulnerability of the SES to a specific adverse driver level or rate depends on the initial well-being, sensitivity, and AC (Adger 2006). We therefore define AC as a set of assets, resources, 
or tools that reduce vulnerability by expanding the "coping range," or range of driver states generating a low probability of adverse outcomes (Smit and Wandel 2006, Kofinas et al. 2013). Although we describe AC specific to environmental and land use change, some components of AC may be useful in a variety of ways, as people respond to cumulative effects of multiple cooccurring drivers (Carpenter et al. 2012). Nevertheless, some components of AC may help mitigate vulnerabilities caused by a specific driver, for example, infrastructure to address flood hazards versus infrastructure to address permafrost thaw, making it necessary to articulate the specific drivers creating potential vulnerabilities to this particular community or region under study. Here we focus on the implications of AC to three forces for change particularly relevant to the region.

\section{Climate change}

Climate change is already affecting Arctic subsistence livelihoods and community living conditions in several ways. The loss of sea ice, changes in seasonality, and warmer temperatures are making hunting more difficult and travel riskier, as well as changing the seasonal distribution of subsistence resources, such as walrus and several seal species (Carson and Peterson 2016, Huntington et al. 2016, IPCC 2019). Diminished shore-fast ice and thawing of permafrost, combined with increased extreme weather events, has hastened coastal erosion (Gibbs and Richmond 2015). Thawing permafrost threatens infrastructure such as roads, buildings, and traditional ice cellars (Arctic Monitoring and Assessment Programme 2017). Climate change increases uncertainty not only through directional change, but also by potentially increasing climate variability.

\section{Oil and gas development}

The NS has been a major oil-producing area since the 1970s. Initially oil and gas activity were limited to the vicinity of Prudhoe Bay, but production and the associated pipeline network now extends west into the Alaska National Petroleum Preserve (Fig. 2), and in nearby offshore areas. Several areas of the Alaska National Petroleum Reserve around Nuiqsut are in various stages of development. This development has had adverse environmental effects that will likely increase as activities expand (Raynolds et al. 2013). Oil exploration has also taken place and could occur in the future around Wainwright and Kaktovik (BLM 2018, 2019). Besides local environmental change, oil development profoundly affects all NSB communities through its role in the cash economy.

\section{Other drivers}

Ecotourism is expanding near Anaktuvuk Pass and Kaktovik, which are surrounded by federal protected areas. Cruise ship tourism is currently limited because of remoteness and lack of infrastructure, but could expand as sea ice retreats, depending on trends in global tourism markets (Lasserre and Pelletier 2011, Lasserre et al. 2016). At some level of increase, tourism could impair harvesting activities (Maher 2007). State and federal policies affect NS communities in numerous ways, including management of federal lands and natural resources, regulation of resource development, tax and spending policies, and devolution of authority to local governments. North Slope communities also confront the same forces of technological change and globalization that affect communities everywhere.

\section{METHODS}

\section{Desirable outcomes and activities to achieve them}

AC may relate to both social and ecological aspects of the SES, and is context specific (Smit and Wandel 2006). Since AC embodies assets that people use to improve SES outcomes, we begin by identifying desirable outcomes and activities that achieve them. North Slope community residents have previously identified community goals that include continued practice of traditional subsistence activities, availability of local jobs, and local autonomy. They have also described desirable futures that include use of Iñupiaq language, high-quality education, public safety, local autonomy, and respect for elders (Kruse et al. 2004, Lovecraft 2017, Blair and Kofinas 2020). Indigenous language and formal education are assets that could assist adaptation (i.e., they are components of AC). Other goals reflect potential SES outcomes. Our assessment of AC for communities of Alaska's NS focused on assets that may help achieve these outcomes directly, or assist activities that could improve them.

North Slope residents engage in a number of activities that reduce the likelihood of adverse outcomes as they adapt to environmental uncertainty and change that are similar or analogous to risk-mitigating activities observed elsewhere in the Arctic and around the world (Agrawal 2010, Lovecraft and Eicken 2011, Berman 2013). Community residents diversify livelihoods by targeting different subsistence species and having some household members work for pay while others harvest wild foods. They share harvests, move among communities, and invest in tools and equipment (Kofinas et al. 2016a). AC assets reduce vulnerability by increasing the effectiveness of these activities to mitigate risk.

\section{Adaptive capacity domains and indicators}

Studies that discuss indicators to measure AC have generally partitioned AC into domains (dimensions) that they use to group sets of related indicators. Authors differ in the articulation of the domains (e.g., Sen 1983, Scoones 1998, Ford and Smit 2004, Tol and Yohe, 2007, Hinkel 2011). With specific reference to the Arctic, Kofinas et al. (2016a) defined seven domains of AC in the Arctic Resilience Report (ARR): natural capital (natural resources and ecosystems providing ecosystem services), social capital (capacity of people to work together to solve problems), cultural capital, human capital (education and skills), financial capital (access to wealth in the market economy), physical infrastructure, and knowledge assets. We adjusted the ARR domains somewhat to fit the NS context (Table 1), dividing natural capital into two subdomains (physical geography and ecosystem health). In other regions, geographic features affecting adaptation might include permafrost/soils, flood hazards, water scarcity, etc.; however, in the North Slope case, what distinguishes communities is their relative remoteness. Another geographic characteristic that distinguishes NS communities is whether they are located inland or on the coast. No coastal community has a harbor, so the primary effect of a coastal location is ecological, as it gives coastal residents access to a greater diversity of harvestable fish and wildlife resources.

The ARR includes institutions and governance systems as part of social capital, while noting that they play an important role in hindering or enabling communities to utilize other AC tools to 
Table 1. Domains, implications to adaptation, and indicators of adaptive capacity for Alaska North Slope communities.

\begin{tabular}{|c|c|c|}
\hline $\begin{array}{l}\text { Adaptive capacity domain } \\
\text { Implications to adaptation }\end{array}$ & Indicator & Measure(s) \\
\hline \multicolumn{3}{|l|}{ Physical geography: remoteness } \\
\hline \multirow{3}{*}{$\begin{array}{l}\text { Remoteness raises the costs of shipping goods and impedes } \\
\text { mobility. }\end{array}$} & Travel cost to urban area & Price and travel time of commercial flight \\
\hline & Air service quality & Number of flight segments, daily jet service \\
\hline & Seasonal road access & Ice road link to road system $(\mathrm{Y} / \mathrm{N})$ \\
\hline \multicolumn{3}{|l|}{ Ecosystem health } \\
\hline \multirow{3}{*}{$\begin{array}{l}\text { Diversity of harvested species improves food security by reducing } \\
\text { dependence on any one potentially uncertain resource; can also } \\
\text { affect human health }\end{array}$} & Ecological diversity & Diversity of potential food sources \\
\hline & Development disturbance & Oil and gas activities near community $(\mathrm{Y} / \mathrm{N})$ \\
\hline & Harvesting opportunities & Subsistence whaling access \\
\hline \multicolumn{3}{|l|}{ Physical infrastructure } \\
\hline \multirow{5}{*}{$\begin{array}{l}\text { Provides housing, medical and fire-fighting services, internet } \\
\text { access, places for community gatherings, roads, water and sewer } \\
\text { services. }\end{array}$} & Housing quality & Crowded housing, plumbing facilities \\
\hline & Housing affordability & Housing cost as percentage of income \\
\hline & Telecommunications access & Fiber optic cable to community (Y/N) \\
\hline & Health care facilities & Hospital in community $(\mathrm{Y} / \mathrm{N})$ \\
\hline & Public safety facilities & Jail in community $(\mathrm{Y} / \mathrm{N})$ \\
\hline \multicolumn{3}{|l|}{ Human capital } \\
\hline $\begin{array}{l}\text { The skill set of residents to know and act, including leadership } \\
\text { and "how to" knowledge }\end{array}$ & Education investment & $\begin{array}{l}\text { Post-secondary education, high-school } \\
\text { graduation, standardized test scores }\end{array}$ \\
\hline \multicolumn{3}{|l|}{ Social and cultural capital } \\
\hline \multirow[t]{4}{*}{$\begin{array}{l}\text { Provides access to resources within and beyond the community; } \\
\text { can support subsistence activities }\end{array}$} & Investment in social capital & $\begin{array}{l}\text { Sharing of subsistence foods among } \\
\text { households }\end{array}$ \\
\hline & Investment in cultural capital & $\begin{array}{l}\text { Subsistence participation: hunting/fishing and } \\
\text { other skills }\end{array}$ \\
\hline & Social and cultural capital & $\begin{array}{l}\text { Per capita whaling crews organized in the } \\
\text { community }\end{array}$ \\
\hline & Access to Indigenous knowledge & Iñupiat language spoken at home \\
\hline \multicolumn{3}{|l|}{ Financial capital } \\
\hline \multirow{3}{*}{$\begin{array}{l}\text { Allows for purchasing goods and services, and making } \\
\text { investments. }\end{array}$} & Diversity of cash economy & Percent employment in local government \\
\hline & Local business strength & $\begin{array}{l}\text { Village corporation dividend paid in recent } \\
\text { years }\end{array}$ \\
\hline & Access to capital & Commercial bank office in community \\
\hline \multicolumn{3}{|l|}{ Institutional capital } \\
\hline Allows community preferences to be considered in various areas & Formal local government & City government incorporated under state law \\
\hline of governance; can affect quality and quantity of most other AC & Cross-scale governance & Representation on co-management boards \\
\hline domains. & Public safety response & Local police officers stationed in community \\
\hline
\end{tabular}

mitigate risks (Hovelsrud et al. 2010) that might otherwise remain latent and not activated (Nelson et al. 2007, Engle 2011). Because of the importance of institutions for the NS case and their role in mobilizing other types of $\mathrm{AC}$, we placed institutions in a separate domain. One may theoretically distinguish cultural capital (shared beliefs and practices) from social capital that embeds these practices in society (social networks and sharing systems); however, we followed Tol and Yohe (2007) and combined them because they are difficult to distinguish empirically in North Slope Inupiat communities. The primary mechanisms for building social capital in these communities involve participation in activities that bring members of different households together as they carry out subsistence livelihoods. Participating in these activities builds cultural capital as well, by transferring traditional ecological knowledge, harvesting and other livelihood skills, and Iñupiaq language across generations

Acknowledging the potential importance of knowledge assets and technology in AC, we omitted them for practical reasons: knowledge assets are difficult to measure, and differences among NSB communities are likely to be slight. Instead, we relied on the human capital and social and cultural capital domains to address the capacity of residents to access and use knowledge assets in their adaptation activities. We addressed some AC domains that are difficult to measure by observing local investments that build unobserved $\mathrm{AC}$ assets. In measuring investment flows to substitute for unobservable asset stocks, however, we avoided relying on SES outcomes such as income or harvest to measure AC. Although many studies include system outcomes like income as a measure of AC (Yohe and Tol 2002, Adger et al. 2004), we find that approach problematic because the outcomes could be sensitive to changes in the drivers and therefore not helpful for reducing vulnerability.

We applied a two-step process for selecting indicators in each of the domains. First, we identified appropriate indicators that were consistent with theory and literature on AC, as it would apply to the North Slope context. Application to North Slope communities was grounded in the authors' knowledge of the region from many years of studies working with individual communities (Kruse et al. 2004, BurnSilver et al. 2016, Kofinas et al. 2016b, Berman et al. 2017). Then we selected specific measures of these indicators based on availability of recent information for all the NS communities, and on measurable community differences. Applying these criteria to the data available for Alaska NS communities, we selected 28 measures of 
Fig. 3. Normalized rank scores and total rank of adaptive capacity (AC) among eight North Slope communities: average ranking across all measures in each domain and sum of rankings (total score) across all domains: $1=$ highest, $8=$ lowest.

\begin{tabular}{|c|c|c|c|c|c|c|c|c|}
\hline & $\begin{array}{l}\text { Physical } \\
\text { geography }\end{array}$ & $\begin{array}{l}\text { Ecosystem } \\
\text { health }\end{array}$ & $\begin{array}{c}\text { Physical } \\
\text { infrastructure }\end{array}$ & $\begin{array}{l}\text { Human } \\
\text { capital }\end{array}$ & $\begin{array}{c}\text { Social and } \\
\text { cultural capital }\end{array}$ & $\begin{array}{c}\text { Financial } \\
\text { capital }\end{array}$ & $\begin{array}{l}\text { Institutional } \\
\text { capital }\end{array}$ & $\begin{array}{l}\text { 1 Total } \\
\text { score }\end{array}$ \\
\hline Anaktuvuk Pass & 2.2 & 5.3 & 4.2 & 6.7 & 3.8 & 4.7 & 4.7 & 31.8 \\
\hline Atqasuk & 3.8 & 5.0 & 3.2 & 5.7 & 5.6 & 5.3 & 1.7 & 30.2 \\
\hline Kaktovik & 3.0 & 4.7 & 3.0 & 2.0 & 4.0 & 3.0 & 2.0 & 21.7 \\
\hline Nuiqsut & 3.0 & 5.7 & 2.3 & 6.7 & 2.8 & 1.3 & 2.3 & 24.1 \\
\hline Point Hope & 4.0 & 1.7 & 3.5 & 4.0 & 4.0 & 3.0 & 3.0 & 23.2 \\
\hline Point Lay & 5.8 & 2.0 & 5.2 & 5.7 & 5.2 & 5.0 & 3.0 & 31.8 \\
\hline Utqiaġvik & 1.4 & 3.3 & 1.3 & 2.0 & 3.6 & 2.3 & 3.3 & 17.3 \\
\hline Wainwright & 4.4 & 3.3 & 4.0 & 3.0 & 4.0 & 3.0 & 4.0 & 25.7 \\
\hline
\end{tabular}

22 indicators to assess AC in the seven domains (Table 1). We used the best available data, acknowledging that incomplete or poorquality data limited the precision of comparisons for some measures. Appendix 1 provides definitions and data sources for all indicators. The literature provides little guidance for determining relative importance of AC domains, and each measure has different units and associated scale. We ranked communities on each measure and constructed measures of comparative $\mathrm{AC}$ for each domain based on the average rank of that community across all measures in that domain. An index of overall community $\mathrm{AC}$ was then derived by adding up the normalized scores within each domain, assuming each domain was equally important. Appendix 2 provides links to an online data repository that contains the data and detailed methods used to calculate the scoring and ranking of $\mathrm{AC}$ within and among the seven domains. The grouping of indicators into domains is inherently somewhat arbitrary: we noted above how different authors grouped similar indicators differently. In addition, legitimate concerns may be raised about the quality of the data available for certain of the indicators. We addressed these concerns by conducting three sensitivity analyses (Appendix 3) that evaluate how aggregation or separation of indicators into domains and data quality issues might affect the consistency of community rankings.

\section{RESULTS}

\section{Measures and community comparisons}

Figure 3 shows the average ranking of North Slope communities based on a set of measures for each AC domain, as well as an overall rank based on the sum of rankings across all domains. The rank order of communities differs for each of the seven domains. However, some communities consistently ranked higher than others across multiple domains. The total scores formed by summing the average rank scores for each domain ranged from 17 to 32 . Utqiagivik, the highest ranked community (lowest total score), never ranked below third place in any domain. Point Lay, the lowest ranked community (highest total score), ranked seventh or eighth in five of the seven domains. The sensitivity analysis indicated that reorganizing indicators to represent domains of $\mathrm{AC}$ as defined in other studies did change the ranking of communities in some cases, as did adding the requirement that measured differences among communities had to exceed a margin error to break ties. However, the communities could be grouped into three tiers that were robust to all specifications. Utqiagivik remained the top-ranked community in all variations (total score $<20$ ), followed by a group of communities with moderate AC that included Kaktovik, Point Hope, Nuiqsut, and Wainwright (total score 20-30). A third group, with the lowest AC (total score $>$ 30), included Point Lay, Atqasuk, and Anaktuvuk Pass. Appendix 3 provides the details of sensitivity analyses conducted and the effects on community rankings.

Within each domain, some highlights serve to illustrate similarities and differences among NS communities that combine to generate the overall scores.

\section{Physical geography/remoteness}

Remoteness raises shipping costs and impedes mobility. We measured remoteness through a variety of measures of air travel and seasonal ice road access to the most affordable urban center containing a full range of consumer and business services (Fairbanks or Anchorage). Utqiagivik had the lowest fares and best air access, with multiple daily jet flights by a major carrier. Travel to Point Lay is the costliest and least convenient.

\section{Ecosystem health}

Diversity of subsistence harvests improves food security by reducing dependence on any one potentially uncertain resource. To assess harvest diversity, we calculated the average annual Simpson's diversity index (Simpson 1949) using total pounds harvested for 11 major subsistence species groups (Fig. 4). Because of the importance of subsistence bowhead (Balaena mysticetus) whaling to the Iñupiat, we also considered whaling opportunities measured by the number of harvest seasons. We assessed potential ecosystem disturbance with a categorical measure of nearby oil and gas activities. Residents of coastal whaling communities distant from oil and gas activities, Point Hope and Point Lay, scored highest for this domain. Although located somewhat inland, Nuiqsut residents participate in fall whaling and other coastal subsistence activities. However, the community is heavily affected by oil development, causing concern among residents about its effects on subsistence resources and ecosystem health (DeMarban 2017).

\section{Physical infrastructure}

The quality of community infrastructure affects quality of life and multiple community goals. Housing shortages beset many NS communities, but the degree varies, with Utqiagivik least 
overcrowded ( $20 \%$ living with $>1$ person per room) and Point Lay the most overcrowded (49\%). Although Nuiqsut is overcrowded $(43 \%)$, it has the least problems with housing affordability. Utqiagivik, Nuiqsut, Point Hope, and Wainwright have faster internet service, which is important in today's connected world, delivered via fiber optic cable versus satellite service as available in other NS communities (ASTAC 2018). Utqiagivik is the only community with a local hospital and jail.

Fig. 4. Average annual Simpson's Diversity Index for subsistence harvest species in North Slope communities. Survey years are enclosed in parentheses. Blue bars represent coastal communities, yellow bars communities near the coast, and orange bars inland communities. Error bars represent standard deviations. Source: Bacon et al. 2009.

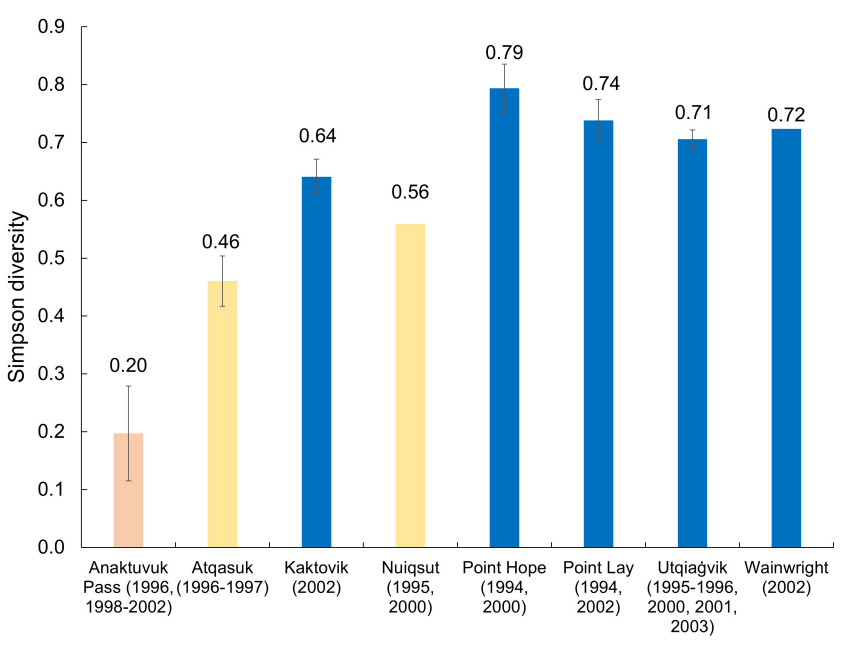

\section{Human capital}

We used high school graduation rates, the percentage of residents with post-secondary education, and standardized test performance to assess human capital. Utqiagivik had the largest percentage of residents with post-secondary education (Fig. 5). However, graduation rates and standardized test scores, i.e., investment in human capital, were highest in Kaktovik. Traditional knowledge (TK) represents another type of human capital, but difficult to measure. We include investment in TK and other cultural assets in social and cultural capital.

\section{Social and cultural capital}

We measured several indicators of investment in social and cultural capital, including wild-food sharing within and outside the community, participation in harvesting and tool-making activities, use of the Indigenous language at home, and number of whaling crews. Sharing networks connect households throughout the NS, helping to buffer fluctuations in harvest success (Bacon et al. 2009, BurnSilver et al. 2016). Broad participation in harvesting activities builds skills and TK, and activities such as sewing and boat making help pass along cultural knowledge (Thornton 2011). Larsen et al. (2014) included language retention as an indicator of control over knowledge construction, as well as an indicator of cultural vitality. Nuiqsut had the largest percentage of households ( $\mathrm{HH})$ engaging in subsistence activities, i.e., hunting, fishing, sled making, etc., and scored moderately high in all other categories. Kaktovik had the most whaling captains (crews) per capita, followed by Utqiagivik and Point Hope. Iñupiaq language was used in at least half of Iñupiat households in Utqiagivik and Wainwright, but in less than a quarter of $\mathrm{HH}$ in Kaktovik and Point Hope.

Fig. 5. Percentage of residents 25 and older with education beyond high school (2009-2017), and high-school graduation rates. Sources: Alaska Department of Education and Early Development: https://education.alaska.gov/data-center; American Community Survey, https://data.census.gov/cedsci/, TableID: C15002C.

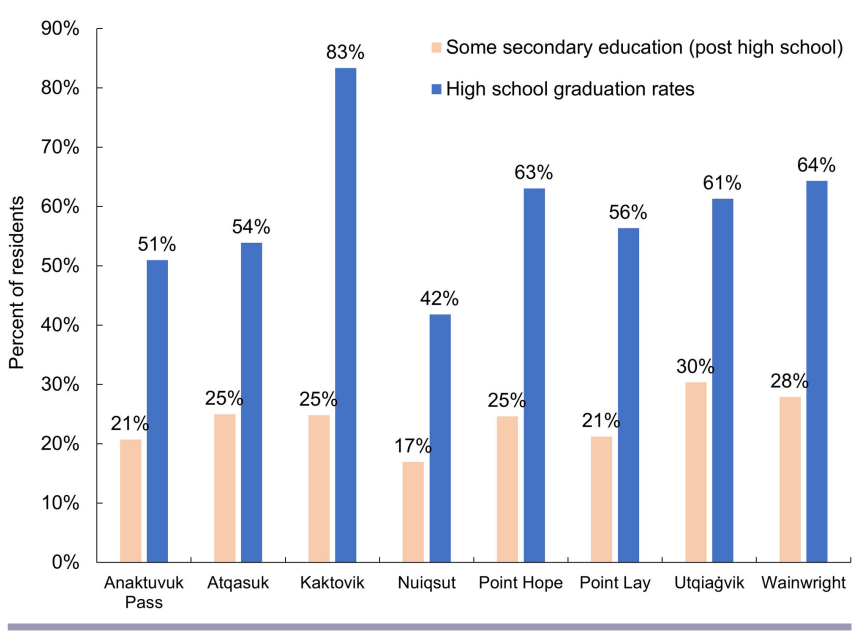

Financial capital

Oil development at Prudhoe Bay and on adjacent lands supports the robust cash economy of all NS communities. The NSB collects property taxes on oil and gas infrastructure (\$386 million in 2016 [Alaska Division of Community and Regional Affairs 2017]) that it uses to create jobs for residents as well as provide services (Knapp and Morehouse 1991, Bell 2016). Most NSB residents also receive dividends from the Alaska Permanent Fund (Berman 2018), the state's sovereign wealth fund, as well as from ASRC, the regional corporation established under the Alaska Native Claims Settlement Act (ANCSA), all derived mostly from oil development. Given that NSB communities showed no systematic differences in access to these funds, we relied on other indicators to assess financial capital: diversity of the cash economy (percentage of employment in local government, negatively ranked), ANCSA village corporation dividends (\$ per share), and presence of a commercial bank office in the community. Government employment may be a source of stability in some regions, such as the Canadian Arctic; however, on the North Slope it is predominantly local government (North Slope Borough), which depends almost entirely on local oil and gas activity. Employment in local government was the lowest in Nuiqsut (51\%) and much higher in Point Lay (76\%), Atqasuk (84\%), and Anaktuvuk Pass (72\%). Nuiqsut also had by far the largest village corporation dividends ( $>\$ 20$ per share). Utqiagivik is the only community with a bank that might provide loans to local small businesses. 


\section{Institutional capital}

Institutions are a key determinant of SES stability and change (Herrfahrdt-Pähle and Pahl-Wostl 2012). NSB residents and communities are embedded in a complex web of formal and informal institutions at multiple scales that affect almost every other domain of AC. Appendix 4 lists the important local, regional, and national formal institutions, along with the role each plays. For assessing differences in community institutional capacity, we focused only on formal institutions. The presence of a state-recognized city government in addition to the federally recognized tribal government, and the number of seats on state and federal subsistence management boards, represented crossscale governance capacity. The number of local police officers per person during a shift indicated emergent response capacity. Point Lay is the only community that lacks an incorporated city government but is tied with Atqasuk for the most NSB police officers per person. Utqiagivik, being a larger community, had the most representatives on subsistence boards but the fewest police officers per capita.

\section{DISCUSSION}

Assessing AC of Arctic communities is an important priority for research on responding to climate and other forces for change (Petrov et al. 2016, Carson et al. 2017). Empirically based measures of adaptive capacity provide information to help community residents and policy makers at all levels determine the short- and long-term allocation of resources for setting resilience pathways (IPCC 2019:271-273). They can also help prepare communities to engage in participatory scenario analysis for the unforeseen consequences of rapid change. Such measures can also contribute to Arctic-wide efforts to establish indicator programs for human well-being (Larson 2010).

Research that compares AC across communities within a consistent generalized framework, however, is limited (Berman et al. 2017, Carson et al. 2017). We used available data to construct indicators and compare AC among NS Alaska communities as it bears on vulnerability and resilience to climate and land use change along with other co-occurring drivers.

Our review of these indicators shows that there are notable differences in AC assets that could affect future vulnerability. Utqiagivik has by far the most physical and social infrastructure among NS communities. Subsistence is strong in all communities, but Utqiagivik has several advantages, including participating in both fall and spring whaling, as well as more whaling crews per capita. Utqiagivik is also the headquarters of the NSB and the ASRC, along with the associated jobs at those headquarters. Utqiagivik is of course somewhat of a special case, being substantially larger than any of the other communities. However, it is far from certain whether the size is a cause of the greater AC or an effect. The federal and also later the state government designated Utqiagivik as the administrative center for the region decades ago. The centralized provision of services and associated infrastructure in such rural Alaska regional centers gave them employment opportunities as well as enhanced AC that attracted migrants from surrounding communities (Howe et al. 2014). The increasing share of population residing in larger settlements is a common pattern across the Arctic (Heleniak 2015).

Assessing the effect of the varying levels of $\mathrm{AC}$ on observed vulnerability and resilience outcomes in the communities is difficult, because the drivers differ by community. Nuiqsut in particular has been affected profoundly by oil development in the area. However, oil development has brought substantial benefits in the form of jobs, dividends, access (reduced remoteness), and reduced living costs at the same time as the environment has become somewhat degraded. Regional environmental change due to climate warming is projected to accelerate in the future, but ongoing adaptation strategies supported by the various $\mathrm{AC}$ components have so far been sufficient to sustain well-being outcomes in all NSB communities. Future climate change, interacting with plausible scenarios for other drivers (e.g., landuse and economic change), however, could pose challenges beyond what residents have experienced in the past. The winding down of oil development on the North Slope could lead to difficult adjustments, particularly for Nuiqsut, which could experience local ecological degradation as well as a loss of employment and income.

The community comparison of indicators also suggests opportunities where targeted investments could address observed weaknesses in AC. Kaktovik, which has not yet experienced local oil development impacts but could if leasing occurs in the surrounding Arctic National Wildlife Refuge, has much higher educational attainment than Nuiqsut. Improving high school outcomes in Nuiqsut, which had the lowest educational attainment among NS communities, could help the community adapt.

Although the indicators suggest that Utqiagivik has greater AC than other communities in the region, smaller communities may enjoy more subtle advantages that are more difficult to measure. For example, smaller communities may have a different quality of social capital that could be helpful in being more responsive and achieving the consensus needed to translate adaptation plans into action. It is difficult to determine a pattern or typology that can explain the difference between the two groups of smaller communities with greater and lesser AC. One characteristic they all have in common is that they are coastal communities or have access to marine subsistence resources. Access to coastal resources provides more ecological diversity, which could make their subsistence harvests more robust to oil development effects. Inland communities like Anaktuvuk Pass and Atqasuk may be able to utilize sharing networks with other communities to compensate for a less diverse pool of subsistence resources. Nuiqsut has the advantage of wealth to "compensate" for lower ecosystem health.

Institutions, especially the NSB, play a major role in all domains of $\mathrm{AC}$ in all study communities. In addition to providing infrastructure, public services, and employment, the NSB offers wildlife-management services that support other local institutions such as co-management organizations and advisory boards that share governance with state, national, and international agencies. The overwhelming importance of the North Slope Borough in providing AC to NS communities makes the NS region in many ways a special case. It is therefore difficult to compare AC in the region to $\mathrm{AC}$ in communities in other rural Alaska regions or to communities in other Arctic nations. Ability to tax extensive local oil infrastructure give the NSB the financial capacity to provide services that other Arctic local governments cannot provide.

Although institutions are clearly important for NSB communities, empirical evidence is limited regarding whether and how some AC assets may be more important than others in 
different contexts. Knowledge of how individual AC domains may interact to generate overall community $\mathrm{AC}$ is also limited. Furthermore, community-level AC is embedded within a panarchy of SES interactions (Chaffin and Gunderson 2016), influenced by household AC and AC at larger scales. Although systematic identification of indicators of $\mathrm{AC}$ is best undertaken through a process of knowledge co-production with local communities, managers, and researchers (Carson et al. 2017), this was not a feasible option in this study with such a large set of communities, although the authors did participate in knowledge co-production studies related to AC in three of the communities (Kofinas et al. 2016b, Berman et al. 2017). Lack of communitylevel data limits what indicators can be measured, and may pose an even bigger challenge than community participation for comparative empirical studies.

\section{CONCLUSION}

We identified and compared measures of 22 indicators of adaptive capacity to environmental change, based on consistency with theory, availability of data, and measurable community differences for the eight communities of Alaska's North Slope. Despite many cultural and institutional similarities among the communities, whose largely Iñupiat population continues to practice a mixed subsistence-cash economy, we found differences among communities for each of the seven AC domains measured. Although every community had strengths in some domains, we could divide communities into three groups with high overall AC (one community), moderate overall AC (four communities), and low overall AC (three communities), based on average rank order across all domains. We also confirmed findings of others regarding the importance of local institutions to adaptive capacity.

We note that identifying empirical patterns that may be useful for policy and transferable to other places requires careful definition and measurement of adaptive capacity. Our analysis suggests that measurable indicators of AC such as those compiled here can increase understanding of the barriers and facilitating conditions for responding to climate and other changes, despite data limitations. Future research into how various domains interact and better methods for pairing empirically measurable indicators of $\mathrm{AC}$ with qualitative case studies of adaptation would provide a richer understanding and improved application to policy making. Studies that retrospectively compare and prospectively assess AC of NSB communities to other Arctic communities could advance a theory of AC and further elucidate opportunities for informing adaption.

Responses to this article can be read online at: https://www.ecologyandsociety.org/issues/responses. php/12304

\section{Acknowledgments:}

The National Science Foundation through Alaska EPSCoR and the State of Alaska provided funds for this project (NSF award \#OIA-1208927)

\section{Data Availability:}

The datalcode that support the findings of this study are openly available in Open Science Framework at https:llosf.iolgzk4fl or DOI https://doi.org/10.17605/OSF.IO/GZK4F.

\section{LITERATURE CITED}

Adger, W. N. 2003. Social capital, collective action, and adaptation to climate change. Economic Geography 79 (4):387-404. https://doi.org/10.1007/978-3-531-92258-4 19

Adger, W. N. 2006. Vulnerability. Global Environmental Change 16(3):268-281. https://doi.org/10.1016/j.gloenvcha.2006.02.006

Adger, W. N., S. Agrawala, M. M. Q. Mirza, C. Conde, K. O'Brien, J. Pulhin, R. Pulwarty, B. Smit, and K. Takahashi. 2007. Assessment of adaptation practices, options, constraints and capacity. Pages 717-774 in M. L. Parry, O. F. Canziani, J. P. Palutikof, P. J. van der Linden, and C. E. Hanson, editors. Climate change 2007: impacts, adaptation and vulnerability. Contribution of Working Group II to the fourth assessment report of the Intergovernmental Panel on Climate Change. Cambridge University Press, Cambridge, UK. [online] URL: https://www. ipcc.ch/site/assets/uploads/2018/02/ar4-wg2-chapter17-1.pdf

Adger, W. N, N. Brooks, G. Bentham, M. Agnew, and S. Eriksen. 2004. New indicators of vulnerability and adaptive capacity. Technical Report 7, Tyndall Centre for Climate Change Research, Norwich, UK.

Agrawal, A. 2010. Local institutions and adaptation to climate change. Pages 173-198 in R. Mearns and A. Norton, editors. Social dimensions of climate change: equity and vulnerability in a warming world. The World Bank, Washington, D.C., USA.

Alaska Division of Community and Regional Affairs. 2017. Alaska Taxable Database. Alaska Department of Commerce, Community, and Economic Development, Juneau, Alaska, USA. [online] URL: https://www.commerce.alaska.gov/dcra/dcrarepoext/ pages/alaskataxabledatabase.aspx

Arctic Monitoring and Assessment Programme. 2017. Adaptation actions for a changing Arctic (AACA): Bering/ Chukchi/Beaufort Region overview report. Arctic Monitoring and Assessment Programme (AMAP), Oslo, Norway. [online] URL: https://www.amap.no/documents/doc/adaptation-actionsfor-a-changing-arctic-aaca-beringchukchibeaufort-region-overviewreport/1531

Anderies, J. M., M. A. Janssen, and E. Ostrom. 2004. A framework to analyze the robustness of social-ecological systems from an institutional perspective. Ecology and Society 9(1):18. https://doi. org/10.5751/ES-00610-090118

Arctic Slope Telephone Association Cooperative (ASTAC). 2018. Residential internet, internet plans. Arctic Slope Telephone Association Cooperative, Anchorage, Alaska, USA. [online] URL https://www.astac.net/residential-internet/internet-plans/

Armitage, D., and R. Plummer, editors. 2010. Adaptive capacity and environmental governance. Springer, New York, New York, USA. https://doi.org/10.1007/978-3-642-12194-4

Bacon, J. J., T. R. Hepa, H. K. Brower Jr, M. Pederson, T. P. Olemaun, J. C. George, and B. G. Corrigan. 2009. Estimates of 
subsistence harvest for villages on the North Slope of Alaska, 1994-2003. Revised October 2011. North Slope Borough Department of Wildlife Management, Barrow, Alaska, USA. [online] URL: http://www.north-slope.org/assets/images/uploads/ MASTER $\% 20$ SHDP $\% 2094-03 \% 20$ REPORT $\% 20$ FINAL $\% 20$ and $\%$ 20\%20Errata \%20info \%20(Sept $\% 202012)$.pdf

Bell, C. 2016. When the North Slope is home: the people, history, and economy outside of Prudhoe Bay. Alaska Economic Trends 36:5-9. [online] URL: http://laborstats.alaska.gov/trends/sep16art1. pdf

Berman, M. 2013. Modeling regional dynamics of humanRangifer systems: a framework for comparative analysis. Ecology and Society 18(4):43 https://doi.org/10.5751/ES-05535-180443

Berman, M. 2018. Resource rents and universal basic income: the permanent fund dividend and poverty among Alaska's Indigenous peoples. World Development 106:161-172. https:// doi.org/10.1016/j.worlddev.2018.01.014.

Berman, M., G. Kofinas, and S. BurnSilver. 2017. Measuring community adaptive and transformative capacity in the Arctic context. Pages 59-75 in G. Fondahl and G. N. Wilson, editors. Northern sustainabilities: understanding and addressing change in the circumpolar world. Springer, Cham, Switzerland. https:// doi.org/10.1007/978-3-319-46150-2 6

Blair, B., and G. Kofinas. 2020. Cross-scale risk perception: differences between tribal leaders and resource managers in Arctic Alaska. Ecology and Society 25(4):9. https://doi.org/10.5751/ ES-11776-250409

Braund, S. R., and J. Kruse, editors. 2009. Synthesis: three decades of research on socioeconomic effects related to offshore petroleum development in coastal Alaska. Stephen R. Braund \& Associates, MMS OCS Study Number 2009-006, Anchorage, Alaska, USA.

Braund, S. R., and J. Kruse, editors. 2010. Subsistence mapping of Nuiqsut, Kaktovik, and Barrow. Stephen R. Braund \& Associates, MMS OCS Study Number 2009-003, Anchorage, Alaska, USA.

Brooks, N., and W. N. Adger. 2005. Assessing and enhancing adaptive capacity. Pages 165-181 in B. Lim, editor. Adaptation policy frameworks for climate change: developing strategies, policies and measures. Cambridge University Press, Cambridge, UK. [online] URL: https://www4.unfccc.int/sites/NAPC/ Country $\% 20$ Documents/General $/$ apf $\% 20$ technical $\% 20$ paper 07 .pdf

Bureau of Land Management. 2018. Alaska oil and gas lease sales. U.S. Department of the Interior BLM, Anchorage, Alaska, USA. [online] URL: https://www.blm.gov/programs/energy-andminerals/oil-and-gas/leasing/regional-lease-sales/alaska

Bureau of Land Management (BLM). 2019. Coastal Plain oil and gas leasing program environmental impact statement. U.S. Department of the Interior BLM, Anchorage, Alaska, USA. [online] URL: https://eplanning.blm.gov/public projects/ nepa/102555/20003762/250004418/Volume 1 ExecSummary Ch1-3 References Glossary.pdf
BurnSilver, S., and J. Magdanz. 2019. Heterogeneity in mixed economies. Hunter Gatherer Research 3(4):601-633. https://doi. org/10.3828/hgr.2017.31

BurnSilver, S., J. Magdanz, R. Stotts, M. Berman, and G. Kofinas. 2016. Are mixed economies persistent or transitional? Evidence using social networks from Arctic Alaska. American Anthropologist 118(1):121-129. https://doi.org/10.1111/aman.12447

Carpenter, S. R., and W. A. Brock. 2008. Adaptive capacity and traps. Ecology and Society 13(2):40. https://doi.org/10.5751/ ES-02716-130240

Carpenter, S. R., J. Kenneth, K. J. Arrow, S. Barrett, R. Biggs, W. A. Brock, A. S. Crépin, G. Engström, C. Folke, T. P. Hughes, N. Kautsky, C. Z. Li, G. McCarney, K. Meng, K. G. Mäler, S. Polasky, M. Scheffer, J. Shogren, T. Sterner, J. R. Vincent, B. Walker, A. Xepapadeas, and A. De Zeeuw. 2012. General resilience to cope with extreme events. Sustainability 4 (12):3248-3259. https://doi.org/10.3390/su4123248

Carson, M., and G. Peterson, editors. 2016. Arctic resilience report. Arctic Council, Stockholm Environment Institute and Stockholm Resilience Centre, Stockholm, Sweden. [online] URL: https://www.sei.org/publications/arctic-resilience-report/

Carson, M., M. Sommerkorn, K. L. Larsen, R. Lawrence, T. Mustonen, C. Strambo, and T. Vlasova. 2017. A resilience approach to adaptation actions. Pages 195-218 in Adaptation action for a changing Arctic (AACA): perspectives from the Barents area. Arctic Monitoring and Assessment Programme (AMAP), Oslo, Norway. [online] URL: https://www.amap.no/ documents/doc/adaptation-actions-for-a-changing-arctic-perspectivesfrom-the-barents-area/1604

Chaffin, B. C., and L. H. Gunderson. 2016. Emergence, institutionalization and renewal: rhythms of adaptive governance in complex social-ecological systems. Journal of Environmental Management 165(1):81-87. https://doi.org/10.1016/j.jenvman.2015.09.003

Chapin, F. S., G. Kofinas, and C. Folke. 2009. A framework for understanding change. Pages 3-28 in F. S. Chapin, G. Kofinas, and C. Folke, editors. Principles of ecosystem stewardship: resilience-based management in a changing world. SpringerVerlag, New York, New York, USA. https://doi.org/10.1007/978-0-387-73033-2 1

Cutter, S., L. Barnes, M. Berry, C. Burton, E. Evans, E. Tate, and J. Webb. 2008. A place-based model for understanding community resilience to natural disasters. Global Environmental Change 18 (4):598-606. https://doi.org/10.1016/j.gloenvcha.2008.07.013

Defiesta, G., and C. Rapera. 2014. Measuring adaptive capacity of farmers to climate change and variability: application of a composite index to an agricultural community in the Philippines. Journal of Environmental Science and Management 17(2):48-62.

DeMarban, A. 2017. ConocoPhillips moves forward with plans to drill near North Slope village. Anchorage Daily News, 30 November. [online] URL: https://www.adn.com/businesseconomy/energy/2017/11/30/conocophillips-moves-forward-withplans-to-drill-near-north-slope-village/ 
Denton, F. 2002. Climate change vulnerability, impacts, and adaptation: why does gender matter? Gender and Development 10(2):10-20.

Ellis, F. 1998. Household strategies and rural diversification. Journal of Developmental Studies 35(1):1-38. https://doi. org $/ 10.1080 / 00220389808422553$

Engle, N. L. 2011. Adaptive capacity and its assessment. Global Environmental Change 21(2):647-656. https://doi.org/10.1016/j. gloenvcha.2011.01.019

Folke, C. 2006. Resilience: the emergence of a perspective for social-ecological systems analyses. Global Environmental Change 16(3): 253-267. https://doi.org/10.1016/j.gloenvcha.2006.04.002

Folke, C., T. Hahn, P. Olsson, and J. Norberg. 2005. Adaptive governance of social-ecological systems. Annual Review of Environmental Resources 30: 441-473. https://doi.org/10.1146/ annurev.energy.30.050504.144511

Ford, J. D., and B. Smit. 2004. A framework for assessing the vulnerability of communities in the Canadian Arctic to risks associated with climate change. Arctic 57(4):325-454. https://doi. org/10.14430/arctic516

Gallopin, G. C. 2006. Linkages between vulnerability, resilience, and adaptive capacity. Global Environmental Change 16 (3):293-303. https://doi.org/10.1016/j.gloenvcha.2006.02.004

Gibbs, A. E., and B. M. Richmond. 2015. National assessment of shoreline change: historical shoreline change along the north coast of Alaska, U.S.-Canadian border to Icy Cape. Open-File Report 2015-1048. U.S. Geological Survey, Reston, Virginia, USA. https://dx.doi.org/10.3133/ofr20151048

Grothmann, T., and A. Patt. 2005. Adaptive capacity and human cognition: the process of individual adaptation to climate change. Global Environmental Change 15(3):199-213. https://doi. org/10.1016/j.gloenvcha.2005.01.002

Heleniak, T. 2015. Arctic populations and migration. Pages 53-104 in J. N. Larsen and G. Fondahl, editors. Arctic human development report: regional processes and global linkages. Nordic Council of Ministers, Copenhagen, Denmark. https://doi. org/10.6027/TN2014-567

Herrfahrdt-Pähle, E., and C. Pahl-Wostl. 2012. Continuity and change in social-ecological systems: the role of institutional resilience. Ecology and Society 17(2):8. http://dx.doi.org/10.5751/ ES-04565-170208

Hinkel, J. 2011. "Indicators of vulnerability and adaptive capacity": towards a clarification of the science-policy interface. Global Environmental Change 21(1):198-208. https://doi. org/10.1016/j.gloenvcha.2010.08.002

Hovelsrud, G. K., and B. Smit, editors. 2010. Community adaptation and vulnerability in Arctic regions. Springer, Dordrecht, Netherlands.

Hovelsrud, G. K., H. Dannevig, J. West, and H. Amundsen. 2010. Adaptation in fisheries and municipalities: three communities in northern Norway. Pages 23-62 in G. K. Hovelsrud and B. Smit, editors. Community adaptation and vulnerability in Arctic regions. Springer, Dordrecht, Netherlands. https://doi. org/10.1007/978-90-481-9174-1 2
Howe, E. L., L. Huskey, and M. D. Berman. 2014. Migration in Arctic Alaska: empirical evidence of the stepping stones hypothesis. Migration Studies 2(1):97-123. https://doi.org/10.1093/ migration/mnt017

Huntington, H.P., L. T. Quakenbush, and M. Nelson. 2016. Effects of changing sea ice on marine mammals and subsistence hunters in northern Alaska from traditional knowledge interviews. Biology Letters 12(8). https://doi.org/10.1098/ $\underline{\text { rsbl.2016.0198 }}$

Intergovernmental Panel on Climate Change (IPCC). 2001. Climate change 2001: impacts, adaptation, and vulnerability. Contribution of Working Group II to the third assessment report of the Intergovernmental Panel on Climate Change. J. J. McCarthy, O. F. Canziani, N. A. Leary, D. J. Dokken, K. S. White, editors. Cambridge University Press, Cambridge, UK. [online] URL: https://www.ipcc.ch/report/ar3/wg2/

Intergovernmental Panel on Climate Change (IPCC). 2014. Summary for policymakers. Pages 1-32 in C. B. Field, V. R. Barros, D. J. Dokken, K. J. Mach, M. D. Mastrandrea, T. E. Bilir, M. Chatterjee, K. L. Ebi, Y. O. Estrada, R. C. Genova, B. Girma, E. S. Kissel, A. N. Levy, S. MacCracken, P. R. Mastrandrea, and L. L. White, editors. Climate change 2014: impacts, adaptation, and vulnerability. Part A: global and sectoral aspects. Contribution of Working Group II to the fifth assessment report of the Intergovernmental Panel on Climate Change. Cambridge University Press, Cambridge, UK. [online] URL: https://www. ipcc.ch/site/assets/uploads/2018/02/ar5 wgII spm en.pdf

Intergovernmental Panel on Climate Change (IPCC). 2019. Special Report on the Ocean and Cryosphere in a Changing Climate. H. O. Pörtner, D. C. Roberts, V. Masson-Delmotte, P. Zhai, M. Tignor, E. Poloczanska, K. Mintenbeck, A. Alegría, M. Nicolai, A. Okem, J. Petzold, B. Rama, N. M. Weyer, editors. International Intergovernmental Panel on Climate Change (IPCC), Cambridge University Press, Cambridge, UK. [online] URL: https://www.ipcc.ch/sroce/

Knapp, G., and T. Morehouse. 1991. Alaska's North Slope Borough revisited. Polar Record 27(163):303-312. https://doi. org/10.1017/S0032247400013061

Kofinas, G., S. Abdelrahim, M. Carson, F. S. Chapin III, J. Clement, N. Fresco, A. Gunn, G. Peterson, A. N. Petrov, A. Quinlan, M. Sommerkorn, and A. Veazey. 2016a. Building resilience in the Arctic: from theory to practice. Pages 180-208 in M. Carson and G. Peterson, editors. Arctic resilience report. Arctic Council, Stockholm Environment Institute and Stockholm Resilience Centre, Stockholm, Sweden. [online] URL: https:// www.sei.org/publications/arctic-resilience-report/

Kofinas, G., S. BurnSilver, J. Magdanz, R. Stotts, and M. Okada. 2016b. Subsistence sharing networks and cooperation: Kaktovik, Wainwright, and Venetie Alaska. BOEM Project report number 2015-023DOI. University of Alaska Fairbanks, Fairbanks, Alaska, USA. [online] URL: https://arctichealth.org/media/ pubs/303436/BOEM-2015-23.pdf

Kofinas, G., D. Clark, G. Hovelsrud, L. Alessa, H. Amundsen, M. Berman, F. Berkes, F. S. Chapin III, B. Forbes, J. Ford, C. Gerlach, and J. Olsen. 2013. Adaptive and transformative capacity. Pages 73-93 in M. Davis and T. Gill, editors. Arctic resilience interim report 2013. Stockholm Environment Institute 
and Stockholm Resilience Centre, Stockholm, Sweden. [online] URL: https://www.sei.org/publications/arctic-resilience-interimreport-2013/

Kruse, J. A., R. G. White, H. E. Epstein, B. Archie, M. Berman, S. R. Braund, F. S. Chapin III, J. Charlie Sr., C. J. Daniel, J. Eamer, N. Flanders, B. Griffith, S. Haley, L. Huskey, B. Joseph, D. R. Klein, G. P. Kofinas, S. M. Martin, S. M. Murphy, W. Nebesky, C. Nicolson, D. E. Russell, J. Tetlichi, A. Tussing, M. D. Walker, and O. R. Young. 2004. Modeling sustainability of Arctic communities: an interdisciplinary collaboration of researchers and local knowledge holders. Ecosystems 7:815-828. https://doi. org/10.1007/s10021-004-0008-Z

Larsen, J. N., editor. 2010. Arctic social indicators: a follow-up to the Arctic Human Development Report. Nordic Council of Ministers, Copenhagen, Denmark.

Larsen, J. N., P. Schweitzer, and A. Petrov, editors. 2014. Arctic social indicators ASI II: implementation. Nordic Council of Ministers, Copenhagen, Denmark. https://doi.org/10.6027/ TN2014-568

Lasserre, F., L. Beveridge, M. Fournier, P. L. Têtu, and L. Huang. 2016. Polar seaways? Maritime transport in the Arctic: an analysis of shipowners' intentions II. Journal of Transport Geography 57:105-114. https://doi.org/10.1016/j.jtrangeo.2016.10.004

Lasserre, F., and S. Pelletier. 2011. Polar super seaways? Maritime transport in the Arctic: an analysis of shipowners' intentions. Journal of Transport Geography 19(6):1465-1473. https://doi. org/10.1016/j.jtrangeo.2011.08.006

Lockwood, M., C. M. Raymond, E. Oczkowski, and M. Morrison. 2015. Measuring the dimensions of adaptive capacity: a psychometric approach. Ecology and Society 20(1):37. https:// doi.org/10.5751/ES-07203-200137

Lovecraft, A. L. 2017. Northern Alaska scenarios project report: creating healthy sustainable communities in Arctic Alaska. Center for Arctic Policy Studies, Fairbanks, Alaska, USA. [online] URL: https://uaf-snap.org/wp-content/uploads/2020/08/NASPReport-2017 small.pdf

Lovecraft, A. L, and H. Eicken. 2011. North by 2020: perspectives on Alaska's changing social-ecological systems. University of Chicago Press, Chicago, Illinois, USA.

Maher, P. T. 2007. Arctic tourism: a complex system of visitors, communities, and environments. Polar Geography 30(1-2):1-5. https://doi.org/10.1080/10889370701666507

Nelson, D. R., W. N. Adger, and K. Brown. 2007. Adaptation to environmental change: contributions of a resilience framework. Annual Review of Environment and Resources 32(1):395-419. https://doi.org/10.1146/annurev.energy.32.051807.090348

Olsson, P., L. H. Gunderson, S. R. Carpenter, P. Ryan, L. Lebel, C. Folke, and C. S. Holling. 2006. Shooting the rapids: navigating transitions to adaptive governance of social-ecological systems. Ecology and Society 11(1):18. https://doi.org/10.5751/ES-01595-110118

Petrov, A. N., S. BurnSilver, F. S. Chapin III, G. Fondahl, J. Graybill, K. Keil, A. E. Nilsson, R. Riedlsperger, and P. Schweitzer. 2016. Arctic sustainability research: toward a new agenda. Polar Geography 39(3):165-178. https://doi. org/10.1080/1088937X.2016.1217095

Raynolds, M. K., D. A. Walker, D. Verbyla, and C. A. Munger. 2013. Patterns of change within a tundra landscape: 22-year Landsat NDVI trends in an area of the Northern Foothills of the Brooks Range, Alaska. Arctic Antarctic and Alpine Research 45 (2):249-260. https://doi.org/10.1657/1938-4246-45.2.249

Scoones, I. 1998. Sustainable rural livelihoods: a framework for analysis. Working paper 72. Institute of Development Studies, Brighton, UK.

Sen, A. 1983. Poverty and famines: an essay on entitlement and deprivation. Oxford University Press, Oxford, UK.

Simpson, E. H. 1949. Measurement of diversity. Nature 163:688. https://doi.org/10.1038/163688a0

Smit, B., and O. Pilifosova. 2001. Adaptation to climate change in the context of sustainable development and equity. Pages 877-912 in J. J. McCarthy, O. F. Canziani, N. A. Leary, D. J. Dokken, K. S. White, editors. Climate change 2001: impacts, adaptation, and vulnerability. Contribution of Working Group II to the third assessment report of the Intergovernmental Panel on Climate Change. Cambridge University Press, Cambridge, UK. [online] URL: https://www.ipcc.ch/report/ar3/wg2/

Smit, B., and O. Pilifosova. 2003. From adaptation to adaptive capacity and vulnerability reduction. Pages 9-28 in J. B. Smith, R. J. T. Klein and S. Huq, editors. Climate change, adaptive capacity and development. Imperial College Press, London, UK. https://doi.org/10.1142/9781860945816 0002

Smit, B., and J. Wandel. 2006. Adaptation, adaptive capacity and vulnerability. Global Environmental Change 16(3):282-292. https://doi.org/10.1016/j.gloenvcha.2006.03.008

Thornton, T. F. 2011. Subsistence in northern communities: lessons from Alaska. The Northern Review 23:82-102. [online] URL https://www.eci.ox.ac.uk/publications/downloads/thornton01subsistence.pdf

Tol, R., and G. Yohe. 2007. The weakest link hypothesis for adaptive capacity: an empirical test. Global Environmental Change 17(2):218-227. https://doi.org/10.1016/j.gloenvcha.2006.08.001

Turner, B. L., R. E. Kasperson, P. A. Matson, J. J. McCarthy, R. W. Corell, L. Christensen, N. Eckley, J. X. Kasperson, A. Luers, M. L. Martello, C. Polsky, A. Pulsipher, and A. Schiller. 2003. A framework for vulnerability analysis in sustainability science. Proceedings of the National Academy of Sciences of the United States of America: Biological sciences. 100(14):8074-8079. https:// doi.org/10.1073/pnas. 1231335100

U.S. Census Bureau. 2011. 2010 Census summary file 1. U.S. Census Bureau, Suitland, Maryland, USA. [online] URL https:// www.census.gov/data/datasets/2010/dec/summary-file-1.html

Walker, B., C. S. Holling, S. R. Carpenter, and A. Kinzig. 2004. Resilience, adaptability and transformability in social--ecological systems. Ecology and society 9(2):5. https://doi.org/10.5751/ ES-00650-090205

Woroniecki, S., R. Krüger, A.-L. Rau, M. S. Preuss, N. Baumgartner, S. Raggers, L. Niessen, L. Holländer, F. Beyers, J. 
Rathgens, K. C. Wagner, L. Habigt, T. Krause, C. Wamsler, H. von Wehrden, and D. Abson. 2019. The framing of power in climate change adaptation research. WIREs Climate Change 10 (6):e617. https://doi.org/10.1002/wcc.617

Yohe, G., and R. Tol. 2002. Indicators for social and economic coping capacity: moving toward a working definition of adaptive capacity. Global Environmental Change 12(1):25-40. https://doi. org/10.1016/S0959-3780(01)00026-7

Young, O. R., H. Schroeder, and L. A. King, editors. 2008. Institutions and environmental change: principal findings, applications, and research frontiers. MIT Press, Boston, Massachusetts, USA. https://doi.org/10.7551/mitpress/9780262240574.001.0001 
Appendix 1. Data sources used to assess adaptive capacity among Alaska North Slope communities.

\begin{tabular}{|c|c|c|c|c|}
\hline $\begin{array}{l}\text { Adaptive } \\
\text { capacity } \\
\text { domain }\end{array}$ & Indicator & Measure & Units & $\begin{array}{l}\text { Data } \\
\text { source }\end{array}$ \\
\hline \multirow[t]{5}{*}{$\begin{array}{l}\text { Physical } \\
\text { geography }\end{array}$} & Remoteness & $\begin{array}{l}\text { Cost of commercial flight to } \\
\text { urban area }\end{array}$ & $\begin{array}{l}\text { \$ per person, } \\
\text { round trip }\end{array}$ & 1 \\
\hline & Remoteness & $\begin{array}{l}\text { Scheduled air travel time to } \\
\text { urban center }\end{array}$ & $\begin{array}{l}\text { Minutes, } \\
\text { round trip }\end{array}$ & 1 \\
\hline & Remoteness & $\begin{array}{l}\text { Air service quality to urban } \\
\text { center, round trip }\end{array}$ & $\begin{array}{l}\text { Number of } \\
\text { flight } \\
\text { segments, } \\
\text { round trip }\end{array}$ & 1 \\
\hline & Remoteness & $\begin{array}{l}\text { Daily jet service to } \\
\text { community }\end{array}$ & $\mathrm{Y} / \mathrm{N}$ & 2 \\
\hline & Remoteness & Ice road link to road system & $\mathrm{Y} / \mathrm{N}$ & 2 \\
\hline \multirow[t]{3}{*}{$\begin{array}{l}\text { Ecosystem } \\
\text { health }\end{array}$} & Ecological diversity & $\begin{array}{l}\text { Harvest diversity, main } \\
\text { subsistence foods (Simpson } \\
\text { diversity index) }\end{array}$ & $\begin{array}{l}0 \text { (no } \\
\text { diversity) to } 1 \\
\text { (infinite } \\
\text { diversity) }\end{array}$ & 3 \\
\hline & $\begin{array}{l}\text { Development } \\
\text { disturbance }\end{array}$ & $\begin{array}{l}\text { Oil and gas activities near } \\
\text { community }\end{array}$ & $\begin{array}{l}\text { Development, } \\
\text { exploration, } \\
\text { none }\end{array}$ & 4 \\
\hline & $\begin{array}{l}\text { Harvesting } \\
\text { opportunities }\end{array}$ & $\begin{array}{l}\text { Number of whaling seasons } \\
\text { annually with a harvest }\end{array}$ & $\begin{array}{l}\text { none, spring } \\
\text { or fall, spring } \\
\text { and fall }\end{array}$ & 5 \\
\hline \multirow[t]{3}{*}{$\begin{array}{l}\text { Physical } \\
\text { infrastructure }\end{array}$} & Housing quality & Crowded housing conditions & $\begin{array}{l}\% \text { households } \\
\text { living with }>1 \\
\text { person/room }\end{array}$ & 6 \\
\hline & Housing quality & Drinking water and sanitation & $\begin{array}{l}\% \text { of } \\
\text { households } \\
\text { with complete } \\
\text { plumbing }\end{array}$ & 6 \\
\hline & Housing cost & $\begin{array}{l}\text { Housing cost as percentage of } \\
\text { household income }\end{array}$ & $\begin{array}{l}\% \text { spending }> \\
40 \% \text { of } \\
\text { income for } \\
\text { housing }\end{array}$ & 6 \\
\hline
\end{tabular}




\begin{tabular}{|c|c|c|c|c|}
\hline \multirow{4}{*}{$\begin{array}{l}\text { Adaptive } \\
\text { capacity } \\
\text { domain }\end{array}$} & Indicator & Measure & Units & $\begin{array}{l}\text { Data } \\
\text { sourc }\end{array}$ \\
\hline & $\begin{array}{l}\text { Telecommunications } \\
\text { access }\end{array}$ & $\begin{array}{l}\text { Fiber optic cable to } \\
\text { community }\end{array}$ & $\mathrm{Y} / \mathrm{N}$ & 7 \\
\hline & Health care facilities & Hospital in community & $\mathrm{Y} / \mathrm{N}$ & 2 \\
\hline & $\begin{array}{l}\text { Public safety } \\
\text { facilities }\end{array}$ & Jail in community & $\mathrm{Y} / \mathrm{N}$ & 8 \\
\hline \multirow[t]{3}{*}{$\begin{array}{l}\text { Human } \\
\text { capital }\end{array}$} & $\begin{array}{l}\text { Educational } \\
\text { attainment }\end{array}$ & $\begin{array}{l}\text { Any secondary education } \\
\text { (post high school), Alaska } \\
\text { Native people }\end{array}$ & $\begin{array}{l}\% \text { persons age } \\
25 \text { and older, } \\
2005-2017\end{array}$ & 6 \\
\hline & $\begin{array}{l}\text { Educational } \\
\text { investment }\end{array}$ & High school graduation & $\begin{array}{l}\% \text { graduating } \\
\text { within } 5 \text { years, } \\
2009-2017\end{array}$ & 9 \\
\hline & $\begin{array}{l}\text { Education } \\
\text { investment }\end{array}$ & $\begin{array}{l}\text { Proficiency on standardized } \\
\text { reading, writing, math, and } \\
\text { science academic } \\
\text { achievement tests }\end{array}$ & $\begin{array}{l}\text { Ave. } \% \\
\text { proficient, } \\
2009-2013\end{array}$ & 9 \\
\hline \multirow[t]{5}{*}{$\begin{array}{l}\text { Social and } \\
\text { cultural } \\
\text { capital }\end{array}$} & $\begin{array}{l}\text { Investment in social } \\
\text { capital }\end{array}$ & $\begin{array}{l}\text { Sharing of subsistence foods } \\
\text { among households }\end{array}$ & $\begin{array}{l}\% \text { HHs } \\
\text { sharing within } \\
+\% \text { sharing } \\
\text { outside } \\
\text { community }\end{array}$ & 10 \\
\hline & $\begin{array}{l}\text { Investment in } \\
\text { cultural capital }\end{array}$ & $\begin{array}{l}\text { Participation in subsistence } \\
\text { harvesting activities }\end{array}$ & $\begin{array}{l}\% \mathrm{HHs} \\
\text { hunting }+\% \\
\text { fishing }\end{array}$ & 10 \\
\hline & $\begin{array}{l}\text { Investment in } \\
\text { cultural capital }\end{array}$ & $\begin{array}{l}\text { Investment in production of } \\
\text { subsistence cultural assets }\end{array}$ & $\begin{array}{l}\% \text { HHs } \\
\text { making sleds, } \\
\text { boats, or } \\
\text { clothes }\end{array}$ & 10 \\
\hline & $\begin{array}{l}\text { Social and cultural } \\
\text { capital }\end{array}$ & $\begin{array}{l}\text { Whaling crews organized in } \\
\text { the community }\end{array}$ & $\begin{array}{l}\text { Whaling } \\
\text { captains per } \\
1000 \text { Iñupiat } \\
\text { pop. }\end{array}$ & 11 \\
\hline & $\begin{array}{l}\text { Access to } \\
\text { Indigenous } \\
\text { knowledge }\end{array}$ & $\begin{array}{l}\text { Mostly Iñupiat or both Iñupiat } \\
\text { and English spoken at home }\end{array}$ & $\begin{array}{l}\% \text { of Iñupiaq } \\
\text { households, } \\
2015\end{array}$ & 10 \\
\hline
\end{tabular}




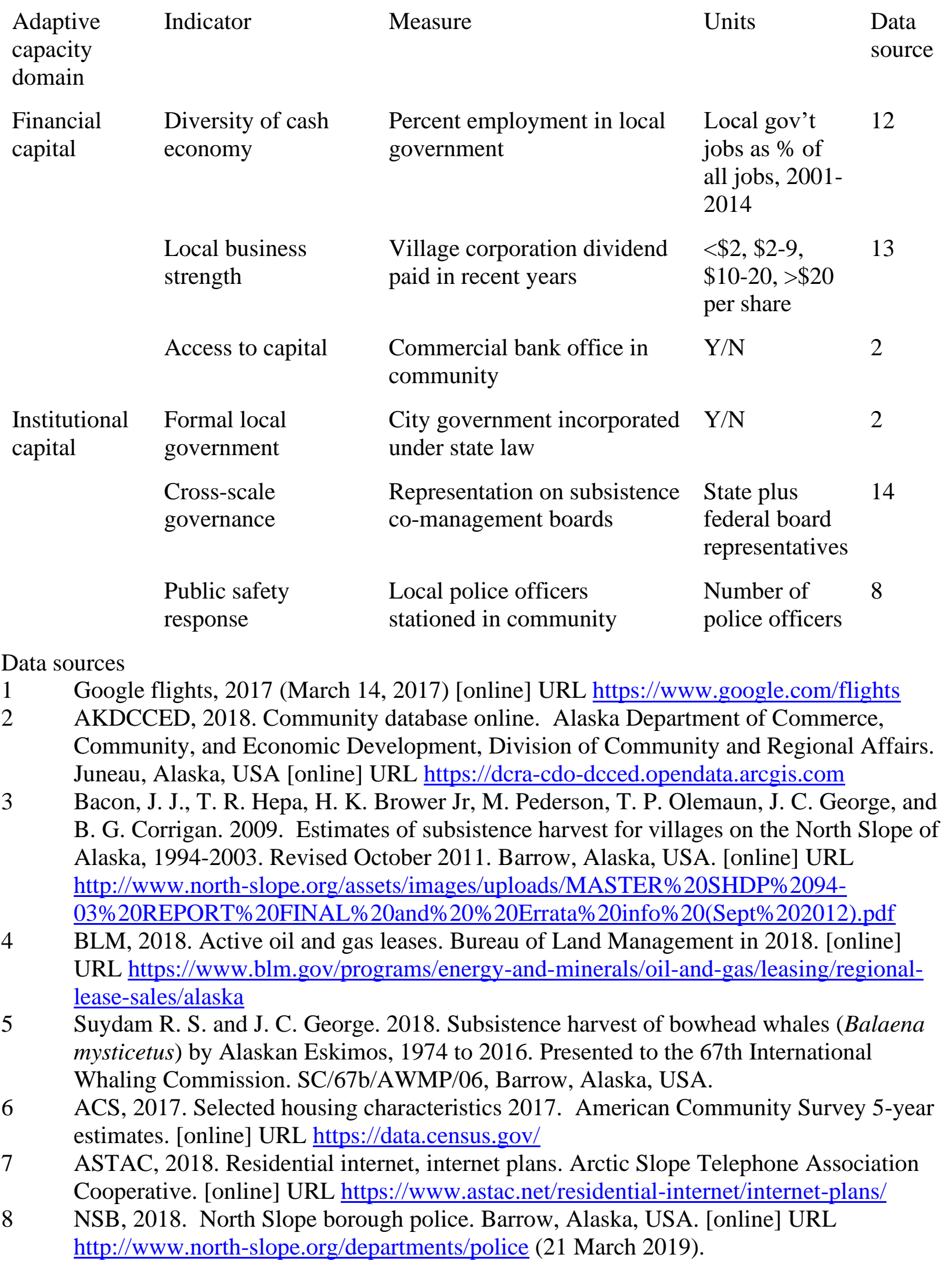


9 ASD, 2019. Graduation data. Alaska Department of Education and Early Development [online] URL https://education.alaska.gov/data-center

10 NSB, 2015. North Slope Census 2015 economic profile and census report. North Slope Borough, Barrow, Alaska, USA. [online] URL http://www.north-slope.org/yourgovernment/nsb-2015-economic-profile-census-report

11 AEWC, 2018. Alaska Eskimo whaling commission in 2018. [online] URL http://www.aewc-alaska.org/whaling-villages.html, and ACS, 2018. Selected social characteristics in the United States in 2018. American Community Survey 5-year estimates. [online] URL https://data.census.gov/

12 ADLWD, 2017. Worker characteristics. Alaska Department of Labor and Workforce Development (ADLWD), Juneau, Alaska, USA. [online] URL http://live.laborstats.alaska.gov/alari

13 Village Corporation web sites, accessed March 21, 2019

14 ADFG 2018. North Slope advisory committee. [online] URL http://www.adfg.alaska.gov/index.cfm?adfg=process.acinfo\&ac=arctic (21 March 2019) and USFWS 2018. North Slope subsistence regional advisory council members. U.S. Fish and Wildlife Service, Anchorage, Alaska, USA. [online] URL https://www.doi.gov/subsistence/regions/ns_members (21 March 2019) 
Appendix 2. Data and methods used to assess adaptive capacity among North Slope communities. This file is openly available online with the formulas used to calculate ranks (Web Table 2) at Open Science Framework at https://osf.io/gzk4f/, reference number DOI 10.17605/OSF.IO/GZK4F. HH = household. 1 = highest, $8=$ lowest.

Color key from rank order:

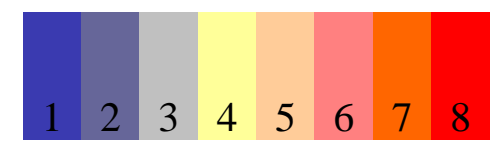

Table A2.1 Geography - data

$\begin{array}{lccccc} & \begin{array}{c}\text { Minimum cost of round- } \\ \text { trip commercial flight to } \\ \text { urban area }\end{array} & \begin{array}{c}\text { Minimum time to } \\ \text { urban center, } \\ \text { minutes }\end{array} & \begin{array}{c}\text { Minimum \# of flight } \\ \text { segments to urban } \\ \text { center, round trip }\end{array} & \begin{array}{c}\text { Daily jet } \\ \text { service } \\ \text { (Y/N) }\end{array} & \begin{array}{c}\text { Ice road link to road } \\ \text { system (Y/N) }\end{array} \\ \text { Anaktuvuk Pass } & \$ 383 & 200 & 2.0 & \text { No } & \text { No } \\ \text { Atqasuk } & \$ 673 & 695 & 2.0 & \text { No } & \text { Yes (3rd) } \\ \text { Kaktovik } & \$ 473 & 500 & 2.0 & \text { No } & \text { Yes (closest) } \\ \text { Nuiqsut } & \$ 924 & 420 & 2.0 & \text { No } & \text { No } \\ \text { Point Hope } & \$ 710 & 555 & 2.0 & \text { Yes } & \text { Yes }(2 n d) \\ \text { Point Lay } & \$ 936 & 730 & 1.5 & 3.0 & \text { No }\end{array}$

Table A2.2 Geography - rank

Anaktuvuk Pas
Atqasuk
Kaktovik
Nuiqsut
Point Hope
Point Lay

Cost to nearest

Travel time (Dept to

\# of flights to get to and

Ice Road to urban area arrival, shortest)

from an urban center Urban $(\mathrm{Y} / \mathrm{N})$

\begin{tabular}{|l|l|}
\hline 2 & 1 \\
\hline 5 & 7 \\
\hline 3 & 4 \\
\hline 7 & 3 \\
\hline 6 & 6 \\
\hline 8 & 8 \\
\hline
\end{tabular}
Jet

\begin{tabular}{|l|}
4 \\
3 \\
4 \\
\hline 1 \\
\hline 4 \\
4
\end{tabular}


Utqiag்ik
Wainwright

Table A2.3 Ecosystems - data
Harvest diversity

(Simpson diversity index)

\section{Anaktuvuk Pass}

Atqasuk

Kaktovik

Nuiqsut

Point Hope

Point Lay

Utqiagivik

Wainwright
0.20

0.46

0.64

0.56

0.79

0.74

0.71

0.72
Number of bowhead

Oil and Gas Activities near community in 2019

harvest seasons with a harvest
0
0
1
1
1
1
2
2

Table A2.4 Ecosystems - data

Anaktuvuk Pass

Atqasuk

Kaktovik

Nuiqsut

Point Hope

Point Lay

Utqiag̀vik

Wainwright

\begin{tabular}{ccc}
$\begin{array}{c}\text { Harvest diversity (Simpson } \\
\text { diversity index) }\end{array}$ & $\begin{array}{c}\text { Oil and Gas Activities near } \\
\text { community in 2019 }\end{array}$ & $\begin{array}{c}\text { Number of bowhead harvest } \\
\text { seasons with a harvest }\end{array}$ \\
\hline 8 & 1 & 7 \\
7 & 1 & 7 \\
5 & 6 & 3 \\
6 & 8 & 3 \\
1 & 1 & 3 \\
2 & 1 & 3 \\
4 & 5 & 1 \\
3 & 6 & 1
\end{tabular}


Table A2.5 Physical infrastructure - data

\begin{tabular}{|c|c|c|c|c|c|c|}
\hline & $\begin{array}{c}\text { Overcrowding } \\
\text { (more than } 1 \text { people } \\
\text { per room) }\end{array}$ & $\begin{array}{c}\% \text { of households that } \\
\text { use }>40 \% \text { of } \\
\text { income for housing }\end{array}$ & Fiber optic cable & $\begin{array}{l}\% \text { of } \mathrm{HH} \\
\text { with } \\
\text { pluming }\end{array}$ & Hospital & Jail \\
\hline Anaktuvuk Pass & $32 \%$ & $12 \%$ & No & $86 \%$ & No & No \\
\hline Atqasuk & $29 \%$ & $7 \%$ & No & $86 \%$ & No & No \\
\hline Kaktovik & $22 \%$ & $9 \%$ & No & $92 \%$ & No & No \\
\hline Nuiqsut & $45 \%$ & $1 \%$ & Yes & $95 \%$ & No & No \\
\hline Point Hope & $37 \%$ & $8 \%$ & Yes & $83 \%$ & No & No \\
\hline Point Lay & $47 \%$ & $9 \%$ & No & $57 \%$ & No & No \\
\hline Utqiaġvik & $21 \%$ & $5 \%$ & Yes & $92 \%$ & Yes & Yes \\
\hline Wainwright & $33 \%$ & $9 \%$ & Yes & $79 \%$ & No & No \\
\hline
\end{tabular}

Table A2.6 Physical infrastructure - rank

\begin{tabular}{|c|c|c|c|c|c|c|}
\hline & $\begin{array}{l}\text { Overcrowding } \\
\text { (more than } 1 \\
\text { people per room) }\end{array}$ & $\begin{array}{l}\% \text { of households } \\
\text { that use }>40 \% \text { of } \\
\text { income for } \\
\text { housing }\end{array}$ & Fiber optic cable & $\begin{array}{l}\% \text { of } \mathrm{HH} \text { with } \\
\text { pluming }\end{array}$ & Hospital & Jail \\
\hline Anaktuvuk Pass & 4 & 8 & 5 & 4 & 2 & 2 \\
\hline Atqasuk & 3 & 3 & 5 & 4 & 2 & 2 \\
\hline Kaktovik & 2 & 5 & 5 & 2 & 2 & 2 \\
\hline Nuiqsut & 7 & 1 & 1 & 1 & 2 & 2 \\
\hline Point Hope & 6 & 4 & 1 & 6 & 2 & 2 \\
\hline Point Lay & 8 & 5 & 5 & 8 & 2 & 2 \\
\hline Utqiaġvik & 1 & 2 & 1 & 2 & 1 & 1 \\
\hline Wainwright & 5 & 5 & 1 & 7 & 2 & 2 \\
\hline
\end{tabular}

Table A2.7 Human capital - data 
Some secondary education (post high school) (2009-2017)

Anaktuvuk Pass

Atqasuk

Kaktovik

Nuiqsut

Point Hope

Point Lay

Utqiagivik

Wainwright
Graduation Rates (2009-2017)

$49 \%$

$49 \%$

$84 \%$

$36 \%$

$62 \%$

$55 \%$

$60 \%$

$57 \%$
Average percent of students proficient on academic achievement tests (20092013) $25 \%$ $17 \%$ $25 \%$ $21 \%$ $30 \%$ $28 \%$

Table A2.8 Human capital - rank
Some secondary education (post high school) (2009-

$$
\text { 2017) }
$$

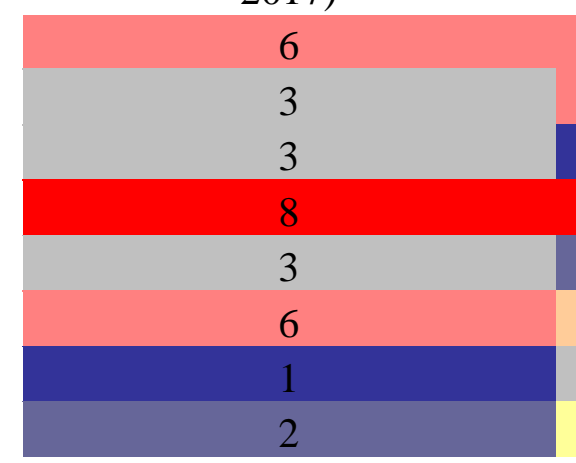

Graduation Rates (2009-2017)
$24 \%$ $19 \%$ $44 \%$ $32 \%$ $26 \%$ $25 \%$ $38 \%$ $37 \%$

Anaktuvuk Pass

Atqasuk

Kaktovik

Nuiqsut

Point Hope

Point Lay

Utqiag̀vik

Wainwright

Average percent of students proficient on academic achievement tests

Table A2.9 Social and cultural capital - data 
Sum of the percent of households

sharing within and outside the community, rounded

Anaktuvuk Pass

$150 \%$

Atqasuk

Kaktovik

Nuiqsut

Point Hope

Point Lay

Utqiagivik

Wainwright
Percent of $\mathrm{HH}$ that hunt and fish, rounded

$105 \%$

$95 \%$

$120 \%$

$120 \%$

$75 \%$

$80 \%$

$70 \%$

$80 \%$
Per capita bowhead whale captains (\#

Make sleds, boats, or clothes

$18 \%$

$7 \%$

$16 \%$

$28 \%$

$18 \%$

$12 \%$

$17 \%$

$13 \%$
Mostly Iñupiat or both Iñupiat and English spoken in Iñupiaq households (2015)

$$
1000
$$

Table A2.10 Social and cultural capital - rank

\begin{tabular}{|c|c|c|c|c|c|}
\hline & $\begin{array}{l}\text { Sum of the } \\
\text { percent of } \\
\text { households } \\
\text { sharing within } \\
\text { and outside the } \\
\text { community }\end{array}$ & $\begin{array}{l}\text { Percent of } \mathrm{HH} \\
\text { that hunt and fish }\end{array}$ & $\begin{array}{c}\text { Make sleds, } \\
\text { boats, or clothes }\end{array}$ & $\begin{array}{l}\text { Per capita bowhead whale } \\
\text { captains (\# } \\
\text { captains/population) } * 1000\end{array}$ & $\begin{array}{l}\text { Mostly Iñupiat or } \\
\text { both Iñupiat and } \\
\text { English spoken } \\
\text { in Iñupiaq } \\
\text { households } \\
(2015)\end{array}$ \\
\hline Anaktuvuk Pass & 4 & 3 & 2 & 7 & 3 \\
\hline Atqasuk & 4 & 4 & 8 & 7 & 5 \\
\hline Kaktovik & 4 & 1 & 5 & 1 & 7 \\
\hline Nuiqsut & 3 & 1 & 1 & 5 & 4 \\
\hline Point Hope & 1 & 7 & 2 & 3 & 8 \\
\hline Point Lay & 2 & 5 & 7 & 6 & 6 \\
\hline Utqiaġvik & 4 & 8 & 4 & 2 & 1 \\
\hline
\end{tabular}


Table A2.11 Financial capital - data

$\begin{array}{lcc} & \begin{array}{c}\text { Percent employment in local } \\ \text { government }(2001-2014)\end{array} & \begin{array}{c}\text { Village corporation dividend (\$ } \\ \text { per share) }\end{array} \\ \text { Anaktuvuk Pass } & 72 \% & <\$ 2 \\ \text { Atqasuk } & 84 \% & <\$ 2 \\ \text { Kaktovik } & 59 \% & \$ 2-\$ 10 \\ \text { Nuiqsut } & 51 \% & >\$ 20 \\ \text { Point Hope } & 58 \% & \$ 2-\$ 10 \\ \text { Point Lay } & 76 \% & <\$ 2 \\ \text { Utqiagivik } & 55 \% & \$ 2-\$ 10 \\ \text { Wainwright } & 60 \% & \$ 10-\$ 20\end{array}$

Bank present
No
No
No
No
No
No
Yes
No

Table A2.12 Financial capital - rank

Village corporation dividend (\$

Anaktuvuk Pass
Atqasuk
Kaktovik
Nuiqsut
Point Hope
Point Lay
Utqiagivik
Wainwright

\begin{tabular}{|ccc|} 
Percent local gov. & $\begin{array}{c}\text { Village corporation dividend }(\$ \\
\text { per share })\end{array}$ & Bank present \\
\hline 6 & 6 & 2 \\
8 & 6 & 2 \\
\hline 4 & 3 & 2 \\
1 & 1 & 2 \\
\hline 3 & 4 & 2 \\
7 & 6 & 2 \\
\hline 2 & 4 & 2 \\
\hline 5 & 2 & 1 \\
\hline
\end{tabular}

Table A2.13 Institutional capital - data 
Anaktuvuk Pass

Atqasuk

Kaktovik

Nuiqsut

Point Hope

Point Lay

Utqiagivik

Wainwright
City government

Yes

Yes

Yes

Yes

Yes

No

Yes

Yes
Total seats on subsistence boards

1

2

2

2

2

1

7

1
Local police officers

1
1
1
2
2
1
8
2

Table A2.14 Institutional capital - data

\begin{tabular}{lccc} 
& \multicolumn{2}{c}{} & Representation on subsistence \\
boards & Local police officers & 5 \\
Anaktuvuk Pass & 1 & 6 & 5 \\
Atqasuk & 1 & 2 & 5 \\
Kaktovik & 1 & 2 & 2 \\
Nuiqut & 1 & 2 & 2 \\
Point Hope & 1 & 2 & 5 \\
Point Lay & 2 & 6 & 1 \\
Utqiagivik & 1 & 1 & 2 \\
Wainwright & 1 & 6 &
\end{tabular}


Appendix 3. Sensitivity analysis of metrics used to assess adaptive capacity among North Slope communities. This file is available online (Web Table 3). These are openly available at Open Science Framework at https://osf.io/gzk4f/, reference number DOI 10.17605/OSF.IO/GZK4F.

Table A3.1 Original framing, indicator averages.

\begin{tabular}{|c|c|c|c|c|c|c|c|c|c|c|}
\hline & Geography & Ecosystems & $\begin{array}{c}\text { Physical } \\
\text { Infrastructure }\end{array}$ & $\begin{array}{l}\text { Human } \\
\text { Capital }\end{array}$ & $\begin{array}{c}\text { Social and } \\
\text { Cultural Capital }\end{array}$ & $\begin{array}{c}\text { Financial } \\
\text { Capital }\end{array}$ & $\begin{array}{l}\text { Institutional } \\
\text { Capital }\end{array}$ & $\begin{array}{l}\text { Total } \\
\text { score }\end{array}$ & Rank & $\begin{array}{l}\text { General } \\
\text { group }\end{array}$ \\
\hline Anaktuvuk Pass & 2.2 & 5.3 & 4.2 & 6.7 & 3.8 & 4.7 & 4.0 & 30.8 & 6th & 3 \\
\hline Atqasuk & 3.8 & 5.0 & 3.2 & 5.7 & 5.6 & 5.3 & 2.7 & 31.2 & 7 th & 3 \\
\hline Kaktovik & 3.0 & 4.7 & 3.0 & 2.0 & 3.6 & 3.0 & 2.7 & 21.9 & 2nd & 2 \\
\hline Nuiqsut & 3.0 & 5.7 & 2.3 & 6.7 & 2.8 & 1.3 & 1.7 & 23.5 & 4 th & 2 \\
\hline Point Hope & 4.0 & 1.7 & 3.5 & 4.0 & 4.2 & 3.0 & 1.7 & 22.0 & $3 r d$ & 2 \\
\hline Point Lay & 5.8 & 2.0 & 5.2 & 5.7 & 5.2 & 5.0 & 4.3 & 33.2 & 8th & 3 \\
\hline Utqiaġvik & 1.4 & 3.3 & 1.3 & 2.0 & 3.8 & 2.3 & 1.0 & 15.2 & $1 \mathrm{st}$ & 1 \\
\hline Wainwright & 4.4 & 3.3 & 3.7 & 3.0 & 4.2 & 3.0 & 3.0 & 24.6 & 5 th & 2 \\
\hline
\end{tabular}

Table A3.2 Sensitivity framing, indicator averages.

\begin{tabular}{|c|c|c|c|c|c|c|c|c|c|c|c|c|}
\hline & Geography & Ecosystems & $\begin{array}{c}\text { Physical } \\
\text { Infrastructure }\end{array}$ & $\begin{array}{l}\text { Human } \\
\text { Capital }\end{array}$ & $\begin{array}{c}\text { Social } \\
\text { and } \\
\text { Cultural } \\
\text { Capital }\end{array}$ & $\begin{array}{c}\text { Financial } \\
\text { Capital }\end{array}$ & $\begin{array}{l}\text { Institutional } \\
\text { Capital }\end{array}$ & $\begin{array}{l}\text { Total } \\
\text { score }\end{array}$ & Rank & $\begin{array}{c}\text { Original } \\
\text { rank }\end{array}$ & $\begin{array}{l}\text { General } \\
\text { group }\end{array}$ & $\begin{array}{l}\text { Original } \\
\text { general } \\
\text { group }\end{array}$ \\
\hline Anaktuvuk Pass & 2.2 & 5.3 & 4.2 & 7.0 & 3.8 & 3.0 & 4.0 & 29.5 & 6 th & 6th & 3 & 3 \\
\hline Atqasuk & 3.8 & 5.0 & 3.2 & 5.7 & 5.8 & 3.7 & 2.7 & 29.8 & 7 th & 7th & 3 & 3 \\
\hline Kaktovik & 3.0 & 4.7 & 2.8 & 2.0 & 4.2 & 4.0 & 2.7 & 23.4 & $3 \mathrm{rd}$ & 2nd & 2 & 2 \\
\hline Nuiqsut & 3.0 & 5.7 & 2.3 & 6.7 & 3.0 & 1.3 & 1.7 & 23.7 & 4 th & 4th & 2 & 2 \\
\hline Point Hope & 4.0 & 1.7 & 3.2 & 4.0 & 4.4 & 3.7 & 1.7 & 22.6 & $2 \mathrm{nd}$ & $3 \mathrm{rd}$ & 2 & 2 \\
\hline Point Lay & 5.8 & 2.0 & 5.0 & 5.7 & 5.4 & 3.3 & 4.3 & 31.5 & 8th & 8th & 3 & 3 \\
\hline Utqiagivik & 1.4 & 3.3 & 1.2 & 2.0 & 4.2 & 3.0 & 1.0 & 16.1 & $1 \mathrm{st}$ & $1 \mathrm{st}$ & 1 & 1 \\
\hline Wainwright & 4.4 & 3.3 & 3.7 & 3.0 & 5.0 & 4.0 & 3.0 & 26.4 & 5 th & 5 th & 2 & 2 \\
\hline
\end{tabular}


Table A3.3 Sensitivity framing, sum of domain ranks.

\begin{tabular}{|c|c|c|c|c|c|c|c|c|c|c|c|c|}
\hline & Geography & Ecosystems & $\begin{array}{l}\text { Physical } \\
\text { Infrastructure }\end{array}$ & $\begin{array}{l}\text { Human } \\
\text { Capital }\end{array}$ & $\begin{array}{c}\text { Social and } \\
\text { Cultural } \\
\text { Capital }\end{array}$ & $\begin{array}{c}\text { Financial } \\
\text { Capital }\end{array}$ & $\begin{array}{l}\text { Institutional } \\
\text { Capital }\end{array}$ & $\begin{array}{l}\text { Total } \\
\text { score }\end{array}$ & Rank & $\begin{array}{l}\text { Original } \\
\text { rank }\end{array}$ & $\begin{array}{l}\text { General } \\
\text { group }\end{array}$ & $\begin{array}{l}\text { Original } \\
\text { general } \\
\text { group }\end{array}$ \\
\hline Anaktuvuk Pass & 2 & 7 & 7 & 8 & 2 & 2 & 7 & 35 & 5 th & 6th & 3 & 3 \\
\hline Atqasuk & 5 & 6 & 4 & 5 & 8 & 5 & 4 & 37 & 6 th & 7 th & 3 & 3 \\
\hline Kaktovik & 3 & 5 & 3 & 1 & 3 & 7 & 4 & 26 & $3 \mathrm{rd}$ & $3 \mathrm{rd}$ & 2 & 2 \\
\hline Nuiqsut & 3 & 8 & 2 & 7 & 1 & 1 & 2 & 24 & 2nd & 2nd & 2 & 2 \\
\hline Point Hope & 6 & 1 & 4 & 4 & 5 & 5 & 2 & 27 & 4 th & 4 th & 2 & 2 \\
\hline Point Lay & 8 & 2 & 8 & 5 & 7 & 4 & 8 & 42 & 8th & 8th & 3 & 3 \\
\hline Utqiagivik & 1 & 3 & 1 & 1 & 3 & 2 & 1 & 12 & $1 \mathrm{st}$ & $1 \mathrm{st}$ & 1 & 1 \\
\hline Wainwright & 7 & 3 & 6 & 3 & 6 & 7 & 6 & 38 & 7 th & 5 th & 2 & 2 \\
\hline
\end{tabular}

Table A3.4 Sensitivity analysis.

\begin{tabular}{|c|c|c|c|c|c|}
\hline & $\begin{array}{c}\text { Average of social and cultural and } \\
\text { institutional }\end{array}$ & $\begin{array}{l}\text { Total } \\
\text { score }\end{array}$ & $\begin{array}{l}\text { Sum of social and cultural and } \\
\text { institutional indicators } / 8\end{array}$ & $\begin{array}{l}\text { Total } \\
\text { score }\end{array}$ & $\begin{array}{l}\text { Original } \\
\text { rank }\end{array}$ \\
\hline Anaktuvuk Pass & 5.8 & 36.8 & 3.9 & 34.9 & 6 th \\
\hline Atqasuk & 6.9 & 35.2 & 4.5 & 32.8 & 7 th \\
\hline Kaktovik & 4.9 & 25.9 & 3.3 & 24.3 & 2nd \\
\hline Nuiqsut & 3.6 & 26.0 & 2.4 & 24.7 & 4 th \\
\hline Point Hope & 5.0 & 24.5 & 3.3 & 22.8 & $3 r d$ \\
\hline Point Lay & 7.4 & 39.7 & 4.9 & 37.2 & 8 th \\
\hline Utqiaġvik & 4.3 & 16.7 & 2.8 & 15.2 & $1 \mathrm{st}$ \\
\hline Wainwright & 5.7 & 29.1 & 3.8 & 27.2 & 5 th \\
\hline
\end{tabular}


Appendix 4. Institutions and Adaptive Capacity for Alaska North Slope Communities ${ }^{a}$

Adaptive Capacity

domain

Geography

Ecosystems

\section{Ecosystems \\ Physical}

infrastructure

(20)

Human capital

Resource protection

Remoteness
Ecosystem health -
terrestrial

Remoteness
Ecosystem health -
terrestrial

Ecosystem health - marine

Category Institutions playing a major role

US DOT (jet service subsidies), USPS (bypass mail)

ADF\&G, NSB Wildlife Management Dept., NPS, USFWS

NOAA, NSB Wildlife Management Dept, co-management boards

NSB Wildlife Management Dept., BLM, subsistence advisory boards, NPS, USFWS, Eskimo Whaling Commission

AHFC, NSB Planning Dept.

NSB utilities, ANTHC, Alaska DCRD, EPA

Water-sewer system

Social and cultural capital

Cash economy
Transportation system

Tele-communications

Formal education

Health care

Traditional knowledge

Social Ties

Language retention

Public safety

Wage employment

NSB Dept. of Public Works

Internet service providers, FCC

NSB School District

AKHSS, Alaska Native Corporations

NSB School District Iñupiat Education

Dept.

Informal sharing networks, whaling crews

NSB School District Iñupiat Education

Dept.

NSB Police, Fire, Search and Rescue

NSB, village corps., ASRC

Diversity of employment opportunities

Public, private, and government entities

Non-wage income

Local government spending capacity
ASRC, village corps., Alaska PF

Oil companies, village corporations, ASRC 
${ }^{a}$ Table abbreviations:

Abbreviation Name

Alaska Division of Community

ADCRD and Regional Development

Alaska Department of Fish and

ADFG Game

ADPH

AEWC

ANTHC

ASNA

ASRC

BLM

BOEM

DOT

EPA

FCC

FWS

NOAA

NPS US National Park Service

NSB North Slope Borough

PFD Permanent Fund Dividend

USPS US Postal Service
Activities

Water and sewer infrastructure grants and services

Fish and wildlife management

Alaska state public health programs

Co-management of subsistence whaling

Water and sewer infrastructure grants and services

Tribal health and social service provider

For-profit regional native corporation, oil land manager

Federal land management, onshore oil leasing

Federal offshore oil leasing

Air service subsidies

Water and sewer infrastructure grants, resource protection

Access to broadband telecommunications services

Fish and wildlife management

Marine mammal management

Land management for federal protected areas

Full range of public services

Universal basic income from the Alaska Permanent Fund

Subsidized mail and freight delivery 